\title{
The General Properties of a Strain of Yeast with Less DNA than Normal
}

\author{
By ELIZABETH M. PARRY \\ Department of Genetics, University College of Swansea, \\ Singleton Park, Swansea, Wales \\ AND B. S. COX \\ Botany School, South Parks Road, Oxford
}

(Accepted for publication 6 October I97I)

\begin{abstract}
SUMMARY
A strain of yeast called $2 \mathrm{~nL}$ is described which behaved genetically as a diploid, but had approximately $18 \%$ less DNA than a normal diploid. It produced apparently normal haploid ascospore cultures, which had approximately $20 \%$ less DNA than normal haploids. The growth of $2 \mathrm{~nL}$ from low yeast concentrations was normal, but at high concentrations it was abnormal; viability was not affected. The timing of DNA synthesis in a synchronously dividing culture was in the usual position in the growth cycle for yeast. DNA was estimated by the diphenylamine reaction; there was no special effect on this reaction, peculiar to $2 \mathrm{~nL}$ and its ascospore cultures. DNA values were confirmed by $A_{\mathbf{2 6 0}}$ measurements. The yeast $2 n L$ was more sensitive to both gamma and u.v. radiations than were normal diploids and there was some indication that defective repair processes were involved.
\end{abstract}

\section{INTRODUCTION}

It was first pointed out by Boivin, Vendrely \& Vendrely (I948) that while the mean amount of DNA in the nucleus varies quite widely from species to species it is apparently constant for the nuclei of the different somatic tissues of a given species. They also noted that the DNA in the haploid sperm nuclei is approximately half of that found in the somatic cell nuclei of the same species. These observations have been confirmed by Mirsky \& Ris (1949, 195I) and subsequently by many workers.

Data from chemical analyses of nuclei in bulk do not reveal possible variations in DNA content from one nucleus to another. To overcome this difficulty attempts have been made to determine the DNA content of individual nuclei by quantitative microspectrophotometric methods (Pollister, Swift \& Alfert, I95I). Such methods are useful for comparative measurements, and have in general confirmed the very narrow range of variation of the nuclear DNA even though the size of the nucleus and its protein content may vary over a wide range. Thus, both methods of DNA estimation indicate that variations in DNA content fall within limits which are narrow enough to make it almost certainly the least variable of all cell components.

The concept that all cells of an organism contain the same quantity of DNA or a geometric multiple of it has been confirmed in a large number of species. In fungi such geometric series with ploidy have been demonstrated in Aspergillus by Heagy \& Roper (1952), in Ustilago maydis by Holliday (196r), and in Saccharomyces cerevisiae by Ogur, 
Minchler, Lindegren \& Lindegren (1952). The technique which the latter used in the extraction of DNA from yeast was that described by Ogur \& Rosen (1949): it has been employed widely in slightly modified forms by many later workers.

During the course of investigations involving the measurement of DNA by the method of Burton (1956, I968), we isolated a strain of yeast which was genetically diploid but showed a consistently low DNA value. The general properties of this strain are described here together with the effect upon DNA estimation of such parameters as yeast numbers and the presence or absence of pigmentation in adenine-dependent cultures.

\section{METHODS}

Yeast strains. The following polyploid series was used. $4 \mathrm{n}: 38 / 8 \mathrm{~d} \times 38 / 3 \mathrm{~d}$ wild-type. 3n: $\mathrm{I} 4 \mathrm{I} / 3 \mathrm{~b} \times(20 \times 20) ; a|a| \alpha$, leuI $\operatorname{trp} 5 /++\mid++$, met2 $|+|+,+\mid a d e 2 / a d e 2{ }^{*} 3 \mathrm{n}: \mathrm{I} 4 \mathrm{I} / 3 \mathrm{~b} \times$ $(2 \mathrm{I} \times 2 \mathrm{I}) ;$ a $|a| \alpha$, leuI $\operatorname{trp} 5 /++1++$, met2 $/+1+,+\mid a d e 2 / a d e 2$. $2 \mathrm{n}: 2 \mathrm{~nJ}$; wild-type, a/ $\alpha$. 2n: 20/20; ade2/ade2, a/ $\alpha . \mathrm{n}$ : indicates combined results for five different haploids; all wildtype.

Cultures of haploids mutant at the adez locus, and diploid cultures homozygous at the adez locus formed red colonies on a complete medium. Adez mutants were blocked at a point in the synthetic pathway concerned with adenine production and this led to the accumulation and polymerization of a red pigment, aminoimidazole carboxylic acid ribonucleotide (Levinthal, Fogel \& Hurst, 1962).

Media and genetic techniques. The complete medium was that described by Cox \& Bevan (1962). Cultures were grown for these experiments on solid medium for three days, at which time there was no cell clumping, no sporulation, and budding was less than $\mathrm{I} \%$. The buds present were of all sizes.

The red coloration in the homozygous adez diploids and adez haploids could be abolished by growing these strains on complete medium supplemented with an excess of adenine to a final concentration of $80 \mu \mathrm{g} / \mathrm{ml}$.

The sporulation medium used was that described by Hurst \& Fogel (1964). The minimal medium used was Difco Yeast Nitrogen Base without amino acids (Difco code 0919-I5-3).

After sporulation the ascus walls were treated with an extract of the fruiting bodies of the common cultivated mushroom (Bevan \& Costello, 1964), and then the asci were dissected by micromanipulation on open complete-medium plates.

A replica-plating technique was used to test cultures for their various nutrient requirements; the series of minimal-medium plates being suitably supplemented with different combinations of growth factors.

DNA measurements. (I) Extraction. Resting phase yeasts were harvested and washed twice in distilled water. Samples were resuspended in distilled water to a measured volume, and the number of yeasts in each sample was counted in a haemocytometer slide. DNA was extracted by a modified procedure of Ogur \& Rosen described by Williamson \& Scopes (I960).

The samples were subjected to two preliminary washes in $10 \%$ trichloroacetic acid at $4^{\circ}$ followed by two washes in $95 \%$ ethanol. The DNA was then extracted in two hot extractions

* The symbols used here and in the text are those agreed upon at the Osaka Yeast Genetics Conference 1969 (Microbial Genetics Bull. no. 31. Yeast Genetics Supplement). The symbols refer to the following phenotypes: leu - leucine requiring, trp - tryptophan requiring, met - methionine requiring, ade - adenine requiring, $a / \alpha$ - mating type gene. The genetic loci are identified by the italicized numbers. 
with $5 \%$ perchloric acid at $70^{\circ}$ for $15 \mathrm{~min}$ each, the yeast debris was removed by centrifugation, and the supernatant fluids were combined for the estimation of their DNA content.

(2) Estimation. The DNA in I $\mathrm{ml}$ of the extracts was estimated colorimetrically by the diphenylamine method of Burton (1956). Calf thymus DNA (British Drug Houses Ltd, Godalming, Surrey) was used as a standard. DNA in the extracts was also determined by measuring their u.v. absorbance at $260 \mathrm{~nm}$.

'Analar' grade chemicals were used.

Rationale of variations in procedure. The effect of variation in yeast cell numbers on the DNA estimations was investigated directly by extracting DNA from samples in a dilution series of cells, i.e. a concentrated suspension of yeast was made as sample I, and gradually reduced portions of this were diluted with appropriate quantities of distilled water to give a series of samples containing different numbers of yeasts in the same volume; such series usually comprised eight samples.

It was conceivable that the extraction procedure would have been more efficient when the sample consisted of a small number of yeasts because of the inefficient circulation of a large number of cells in the extraction liquid. This possibility was tested by diluting the extract obtained from the most concentrated yeast sample, sample I, by the same amounts as the previous cell-dilution series. This gave a dilution series of the extract parallel to the dilution series of yeasts.

It was possible that when extracts from small numbers of yeasts or dilute extracts were measured, the quantities of DNA were below the level that could be accurately measured by the procedures employed. To test this possibility calf thymus DNA was added to each extract to bring the total DNA in the extracts up to easily assayable amounts.

These various procedures were used for the polyploid series of the strains described above and for 2 nL. They were used when all strains had been grown on complete medium and on complete medium supplemented with an excess of adenine. After growth on this latter medium, the strains which had previously been red were white; no difference could be seen in the other strains.

On any one day parallel analyses were run upon at least four different strains. All experiments were repeated at least three times.

Statistical analysis of results. The linear regression analyses of total DNA on number of yeasts analysed, and the curvilinear regression analyses of $\log _{10}$ transformations of DNA per $10^{8}$ cells on number of yeasts analysed were performed by an ICT I900 computer using the program XDS2/19 I.T.C. I900 statistical analysis procedure.

The regression of total DNA $(Y)$ on number of yeasts analysed $(X)$ is approximately described by the equation: $Y=a+b X$. The significance of the regression coefficient, $b$, was given by a $t$ test, and regression lines were plotted for the estimated $Y$ values. The regression coefficient, $b$, is an estimate of the amount of DNA $(\mu \mathrm{g})$ per yeast cell.

The regression of DNA per $10^{8}$ cells on number of yeasts analysed was curvilinear even when logarithmic transformations were used for $X$ and $Y$. This regression was found to be described by a second degree polynomial, $Y=a+b X+c X^{2}$, which introduces the methods of multiple regression. The significance of $b$ was given by a $t$ test, and regression lines were plotted for the estimated $Y$ values.

To test the hypothesis that the slopes of any two regressions were the same, that is, the population regression lines were parallel, the methods of covariance analysis were employed. The variance between the two sample regression coefficients was measured and compared with the variance within samples using the $\mathrm{F}$ test. 
Growth studies. (I) Preparation of a synchronously dividing culture. Synchronously dividing cultures were prepared by the rapid method of Williamson \& Scopes (1962). The synchronized population was rapidly suspended at a concentration of approximately I $\times 10^{7}$ cells $/ \mathrm{ml}$ in a fresh complete medium at $28^{\circ}$, and vigorously aerated. Samples were taken initially and at $30 \mathrm{~min}$ intervals for counting in a haemocytometer slide, and for DNA estimations. Samples $(30 \mathrm{ml})$ were taken for DNA measurements initially, but as the yeast numbers increased the sample size was reduced to $20 \mathrm{ml}$. Samples were treated in the way described by Williamson \& Scopes (I960) to halt growth.

(2) Non-synchronous growth. Stationary phase cultures were harvested from complete medium, washed twice in distilled water and resuspended in fresh complete medium at both low and high yeast concentrations. The cultures were vigorously aerated at $28^{\circ}$. Samples were taken initially and at half-hour intervals in the concentrated culture. The yeast cells were counted in a haemocytometer slide; any bud of diameter greater than onethird that of the parental yeast was counted as one cell. Also suitable dilutions were performed and samples plated on to complete medium plates and scored for colony formation after five days' growth at $28^{\circ}$.

Ultraviolet treatment. The u.v. source was a Hanovia IIA mercury discharge tube generating $97 \%$ of its light at $253.7 \mathrm{~nm}$. Stationary phase yeast suspensions in $5 \mathrm{ml}$ saline at a concentration of approximately $\mathrm{I} \times 10^{7} \mathrm{cells} / \mathrm{ml}$ were exposed to u.v. light at an intensity of $22 \mathrm{erg} / \mathrm{s} / \mathrm{mm}^{2}$ for varying times in an agitated glass Petri dish. The suspensions were shaken vigorously. All manipulations were performed in dim red lighting to avoid photoreactivation, and incubation was at $28^{\circ}$ in the dark.

The lamp was calibrated initially using a chemical actinometer (Hatchard \& Parker, I956), and subsequently by means of a calibrated photoelectric cell.

After irradiation suitable dilutions were prepared and samples plated on complete medium. The plates were scored for visible colony formation after five days' growth at $28^{\circ}$.

Gamma treatment. Cultures were prepared as they were for the estimation of survival after u.v. treatment.

The samples were exposed to $\gamma$-irradiation in air in a 4000 Ci Hotspot Mark IV (U.K. Atomic Energy Authority) for periods of up to five min at a dose rate of $\mathrm{I} 7 \mathrm{krad} / \mathrm{min}$.

\section{RESULTS}

Origin and genetic analysis. The strain $2 \mathrm{~nL}$ arose as a single ascospore isolate from the triploid $\mathrm{I} 4 \mathrm{I} / 3 \mathrm{~b} \times(20 \times 20): a / a \mid \alpha$, leuI $\operatorname{trp} 5|++|++$, met $2|+|+,+\mid$ adez $\mid$ ade 2 .

It was found that $2 \mathrm{~nL}$ did not mate with either $a$ or $\alpha$ mating type haploids; but it did sporulate. Asci were dissected and the percentage spore germination was about $94 \%$. Twenty-one spore tetrads were analysed for the segregation of the above markers; they revealed that the strain $2 \mathrm{~nL}$ appeared to be a normal diploid, heterozygous for the genes leur, trp5, met 2 and the mating type locus, and homozygous for adez. The markers segregated regularly, showing the expected linkage relationships (Mortimer \& Hawthorne, 1966) except that no recombinants were found between met2 and leur. This may indicate that a translocation has occurred between fragment 3 and chromosome VII.

Thirteen tetrads from a spontaneous white form of $2 \mathrm{~nL}$ were analysed: they demonstrated the heterozygosity of all the markers in this culture. As before there was no recombination between met 2 and leur.

The spore cultures $8 \mathrm{a}, 8 \mathrm{c}$ and $\mathrm{Ia}$ from $2 \mathrm{~nL}$ were mated with a strain which had nine 


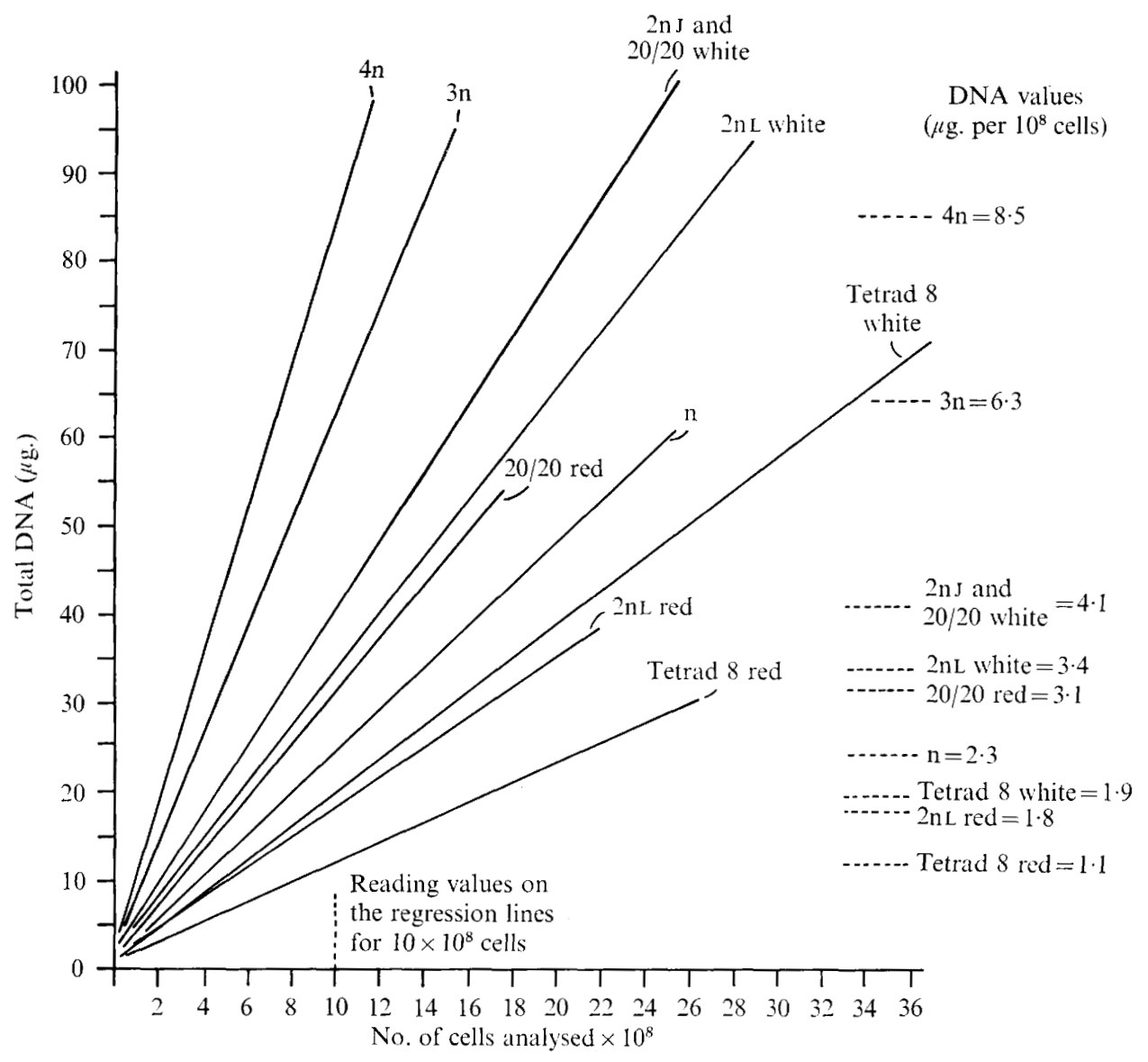

Fig. I. Linear regressions of total DNA content on number of yeasts analysed for all strains. The lines of regression are computer calculated lines of best fit from at least three independent experiments. DNA estimations were made by the diphenylamine reaction.

chromosomes marked. The percentage spore germination from these hybrid diploids was only about $70 \%$. Analysis of 10 tetrads from each of these hybrid diploids revealed normal gene segregation ratios and that recombination between gene pairs was in agreement with established linkage relationships.

DNA measurements. Preliminary determinations of DNA concentrations by the diphenylamine method, revealed that $2 \mathrm{~nL}$ contained less DNA than normal diploids and that the spore cultures were similar to each other in DNA content and were below the normal haploid level. In order to examine the possibility that there was some inhibition of the method of DNA measurement specific to these strains, $2 \mathrm{~nL}$ and the members of two of its spore tetrads, I and 8, were analysed according to the methods described above and compared with the polyploid series.

The results of the analyses of regression of total DNA on the number of yeast cells analysed are summarized in Table $\mathrm{I}$. All regressions are positive and highly significant at the $\mathrm{r} \%$ level except for some of the extracts from red yeasts when measured in the presence of calf thymus DNA, which are negative. Extract dilutions gave similar results to the yeast 
Table I. Summary of linear regression analyses of total DNA $(\mu \mathrm{g})$ on number of yeasts analysed

DNA measurements made upon the extracts alone

DNA measurements made upon the extracts + standard DNA

\begin{tabular}{|c|c|c|c|c|c|c|c|c|c|c|c|c|}
\hline \multirow[b]{2}{*}{ Strain } & \multicolumn{3}{|c|}{ Cell dilutions } & \multicolumn{3}{|c|}{ Extract dilutions } & \multicolumn{3}{|c|}{ Cell dilutions } & \multicolumn{3}{|c|}{ Extract dilutions } \\
\hline & $b$ & $t^{*}$ & $r$ & $b$ & $t^{*}$ & $r$ & $b$ & $t^{*}$ & $r$ & $b$ & $t^{*}$ & $r$ \\
\hline $4 n$ & $\begin{array}{l}8 \cdot 186 \\
8 \cdot 655\end{array}$ & $\begin{array}{r}29.41 \\
109.00\end{array}$ & $\begin{array}{l}I \cdot 00 \\
I \cdot 00\end{array}$ & - & - & - & - & - & - & - & - & - \\
\hline $3 n$ & $\begin{array}{l}6 \cdot 818 \\
5 \cdot 435\end{array}$ & $\begin{array}{l}34 \cdot 81 \\
85 \cdot 77\end{array}$ & $\begin{array}{l}1 \cdot 00 \\
1 \cdot 00\end{array}$ & - & - & - & 二 & - & - & - & - & - \\
\hline $2 n j$ & $\begin{array}{l}3 \cdot 614 \\
3.808 \\
3 \cdot 704 \\
4 \cdot 021 \\
3.450\end{array}$ & $\begin{array}{l}24 \cdot 84 \\
22 \cdot 85 \\
61 \cdot 15 \\
50 \cdot 06 \\
31 \cdot 79\end{array}$ & $\begin{array}{l}I \cdot 00 \\
0 \cdot 99 \\
I \cdot 00 \\
1 \cdot 00 \\
I \cdot 00\end{array}$ & $\begin{array}{c}E \\
\overline{-} \\
4.021 \\
3.505\end{array}$ & $\begin{array}{c}- \\
- \\
94 \cdot 71 \\
103 \cdot 10\end{array}$ & $\begin{array}{l}- \\
\overline{1} \\
1 \cdot 00\end{array}$ & $\begin{array}{l}3 \cdot 417 \\
3 \cdot 436 \\
3 \cdot 249 \\
3 \cdot 228 \\
3 \cdot 224\end{array}$ & $\begin{array}{r}6 \cdot 74 \\
17 \cdot 90 \\
10 \cdot 80 \\
18 \cdot 84 \\
28 \cdot 37\end{array}$ & $\begin{array}{l}0.94 \\
0.99 \\
0.98 \\
0.99 \\
I \cdot 00\end{array}$ & $\begin{array}{l}\bar{Z} \\
\overline{3} \\
3 \cdot 895 \\
3 \cdot 368\end{array}$ & $\begin{array}{c}\bar{Z} \\
\overline{2} \\
24 \cdot 37 \\
14 \cdot 91\end{array}$ & $\begin{array}{l}- \\
\overline{-} \\
0.99 \\
0.99\end{array}$ \\
\hline $20 / 20$ white & $\begin{array}{l}3.660 \\
4.628 \\
3.839\end{array}$ & $\begin{array}{l}34 \cdot 73 \\
24 \cdot 79 \\
44 \cdot 15\end{array}$ & $\begin{array}{l}I \cdot 00 \\
I \cdot 00 \\
I \cdot 00\end{array}$ & $\overline{-}$ & $\overline{-}$ & $\frac{-}{1 \cdot 00}$ & $\begin{array}{l}3.355 \\
3.289 \\
3.692\end{array}$ & $\begin{array}{r}9 \cdot 38 \\
12 \cdot 01 \\
20 \cdot 01\end{array}$ & $\begin{array}{l}0.97 \\
0.98 \\
0.99\end{array}$ & $\begin{array}{l}\overline{-} \\
3.542\end{array}$ & $\frac{\bar{Z}}{12 \cdot 12}$ & $\overline{-}$ \\
\hline $20 / 20 \mathrm{red}$ & $\begin{array}{l}2.528 \\
2.836\end{array}$ & $\begin{array}{r}8 \cdot 02 \\
61 \cdot 60\end{array}$ & $\begin{array}{l}0.96 \\
1 \cdot 00\end{array}$ & $2 \cdot \overline{880}$ & $\frac{-}{17.43}$ & $\overline{0.99}$ & $\begin{array}{r}-17.62 \\
-3.67\end{array}$ & $\begin{array}{l}5 \cdot 23 \\
2 \cdot 79\end{array}$ & $\begin{array}{l}-0.93 \\
-0.75\end{array}$ & $-\overline{8.02}$ & $\overline{7 \cdot 18}$ & $-\overline{0.95}$ \\
\hline 2nL white & $\begin{array}{l}3 \cdot 395 \\
2 \cdot 936\end{array}$ & $\begin{array}{l}37.07 \\
29.67\end{array}$ & $\begin{array}{l}I \cdot 00 \\
I \cdot \infty 0\end{array}$ & $2 \cdot \overline{983}$ & $\overline{231 \cdot 5}$ & $\frac{-}{1 \cdot 00}$ & $\begin{array}{l}2.503 \\
2.660\end{array}$ & $\begin{array}{r}5.96 \\
13.52\end{array}$ & $\begin{array}{l}0.92 \\
0.98\end{array}$ & $\overline{3.002}$ & $\overline{13.05}$ & $\overline{0.98}$ \\
\hline $2 \mathrm{~nL}$ red & $\begin{array}{l}\mathrm{I} \cdot 745 \\
0.920 \\
\mathrm{I} \cdot 807 \\
\mathrm{I} \cdot 088 \\
\mathrm{I} \cdot 658\end{array}$ & $\begin{array}{r}13 \cdot 12 \\
10 \cdot 44 \\
16 \cdot 26 \\
7 \cdot 06 \\
12 \cdot 50\end{array}$ & $\begin{array}{l}0.99 \\
0.98 \\
0.99 \\
0.94 \\
0.98\end{array}$ & $\begin{array}{l}E \\
\overline{1} \\
1 \cdot 910\end{array}$ & $\begin{array}{l}\overline{-} \\
\bar{E} \\
11 \cdot 25\end{array}$ & $\begin{array}{l}- \\
- \\
\overline{0} \\
0.98\end{array}$ & $\begin{array}{c}-\overline{-8 \cdot 58} \\
-5 \cdot 21 \\
- \\
-\end{array}$ & $\begin{array}{l}\overline{-} \\
15.60 \\
6.52 \\
-\end{array}$ & $\begin{array}{l}-\overline{-0.99} \\
-0.94 \\
-\end{array}$ & $\begin{array}{c}\bar{z} \\
-13.36 \\
-\end{array}$ & $\begin{array}{l}\bar{E} \\
\overline{9 \cdot 60} \\
-\end{array}$ & $\begin{array}{l}\bar{z} \\
-0.98 \\
-\end{array}$ \\
\hline $\mathrm{n}$ & $\begin{array}{l}2 \cdot 717 \\
2 \cdot 552 \\
2 \cdot 177 \\
2 \cdot 544 \\
2 \cdot 359\end{array}$ & $\begin{array}{l}15 \cdot 57 \\
30 \cdot 57 \\
64 \cdot 14 \\
19 \cdot 37 \\
25 \cdot 74\end{array}$ & $\begin{array}{l}0 \cdot 99 \\
1 \cdot 00 \\
1 \cdot 00 \\
0 \cdot 99 \\
1 \cdot 00\end{array}$ & $\begin{array}{c}\overline{-} \\
\overline{2} \cdot \overline{6} \\
2 \cdot 040\end{array}$ & $\begin{array}{l}- \\
- \\
39 \cdot 28 \\
33 \cdot 18\end{array}$ & $\begin{array}{l}- \\
\overline{1} \\
1 \cdot 00 \\
1 \cdot 00\end{array}$ & $\begin{array}{l}- \\
I \cdot 636 \\
1 \cdot 583 \\
2 \cdot 117 \\
2 \cdot 329\end{array}$ & $\begin{array}{r}- \\
2 \cdot 18 \\
6 \cdot 76 \\
7 \cdot 59 \\
10 \cdot 28\end{array}$ & $\begin{array}{l}- \\
0.66 \\
0.94 \\
0.96 \\
0.97\end{array}$ & $\begin{array}{l}- \\
- \\
2 \cdot 251 \\
2.637\end{array}$ & $\begin{array}{c}- \\
\bar{Z} \\
11 \cdot 99 \\
4 \cdot 70\end{array}$ & $\begin{array}{l}\overline{-} \\
\bar{z} \\
0.98 \\
0.89\end{array}$ \\
\hline $\begin{array}{r}\text { 2nL/8a white } \\
\text { 8b white } \\
\text { 8c white } \\
\text { 8d white }\end{array}$ & $\begin{array}{l}I \cdot 784 \\
I \cdot 658 \\
I \cdot 926 \\
2 \cdot I 39\end{array}$ & $\begin{array}{l}29.60 \\
23.05 \\
33.60 \\
35.67\end{array}$ & $\begin{array}{l}\mathbf{I} \cdot 00 \\
0.99 \\
\mathbf{I} \cdot 00 \\
I \cdot 00\end{array}$ & $\begin{array}{l}2 \cdot 018 \\
I \cdot 528 \\
I \cdot 945 \\
I \cdot 746\end{array}$ & $\begin{array}{l}4 I \cdot 35 \\
30 \cdot 64 \\
4 I \cdot 34 \\
27 \cdot 36\end{array}$ & $\begin{array}{l}1 \cdot 00 \\
1 \cdot 00 \\
I \cdot 00 \\
1 \cdot 00\end{array}$ & $\begin{array}{l}I \cdot 478 \\
I \cdot 477 \\
I \cdot 885 \\
I \cdot 562\end{array}$ & $\begin{array}{r}5 \cdot 62 \\
13 \cdot 60 \\
5 \cdot 77 \\
11.95\end{array}$ & $\begin{array}{l}0.92 \\
0.98 \\
0.92 \\
0.98\end{array}$ & $\begin{array}{l}- \\
- \\
-\end{array}$ & $\begin{array}{l}- \\
-\end{array}$ & $\overline{-}$ \\
\hline $\begin{array}{r}2 \mathrm{~nL} / 8 \mathrm{a} \text { red } \\
8 \mathrm{~b} \text { red } \\
8 \mathrm{c} \text { red } \\
8 \mathrm{~d} \text { red }\end{array}$ & $\begin{array}{l}I \cdot 038 \\
I \cdot I 20 \\
I \cdot I 43 \\
0.954\end{array}$ & $\begin{array}{l}3 I \cdot 4 I \\
2 I \cdot I 4 \\
I 5 \cdot 02 \\
I 6 \cdot 07\end{array}$ & $\begin{array}{l}1.00 \\
0.99 \\
0.99 \\
0.99\end{array}$ & $\begin{array}{l}0 \cdot 827 \\
0.936 \\
I \cdot 090 \\
I \cdot I 23\end{array}$ & $\begin{array}{r}12.03 \\
9.97 \\
8.49 \\
15.43\end{array}$ & $\begin{array}{l}0.98 \\
0.97 \\
0.96 \\
0.99\end{array}$ & $\begin{array}{l}-2.62 \\
-2.91 \\
-3.09 \\
-3.48\end{array}$ & $\begin{array}{l}3.96 \\
4 \cdot 00 \\
3 \cdot 77 \\
7 \cdot 47\end{array}$ & $\begin{array}{l}-0.85 \\
-0.85 \\
-0.84 \\
-0.95\end{array}$ & $\begin{array}{l}-4.39 \\
-5 \cdot 26 \\
-5.67 \\
-4.65\end{array}$ & $\begin{array}{r}8 \cdot 92 \\
6 \cdot 31 \\
7 \cdot 40 \\
12 \cdot 69\end{array}$ & $\begin{array}{l}-0.97 \\
-0.93 \\
-0.95 \\
-0.98\end{array}$ \\
\hline $\begin{array}{l}\text { 2nL/Ia white } \\
\text { Ib white } \\
\text { Ic white } \\
\text { Id white }\end{array}$ & $\begin{array}{l}I \cdot 4 I 4 \\
I \cdot 497 \\
I \cdot 833 \\
I \cdot 446\end{array}$ & $\begin{array}{l}12 \cdot 26 \\
14.49 \\
12 \cdot 71 \\
45 \cdot 56\end{array}$ & $\begin{array}{l}0.98 \\
0.99 \\
0.98 \\
I \cdot 00\end{array}$ & $\begin{array}{l}- \\
- \\
-\end{array}$ & E & $\begin{array}{l}- \\
-\end{array}$ & $\begin{array}{l}I \cdot 557 \\
I \cdot 826 \\
I \cdot 382 \\
I \cdot 476\end{array}$ & $\begin{array}{r}12 \cdot 21 \\
17 \cdot 70 \\
6 \cdot 68 \\
25 \cdot 56\end{array}$ & $\begin{array}{l}0.98 \\
0.99 \\
0.94 \\
\mathrm{I} \cdot 00\end{array}$ & E & E & E \\
\hline $\begin{array}{l}\text { 2nL/ Ia red } \\
\text { Ib red } \\
\text { Ic red } \\
\text { Id red }\end{array}$ & $\begin{array}{l}I \cdot 223 \\
I \cdot 409 \\
I \cdot 284 \\
I \cdot 288\end{array}$ & $\begin{array}{r}7 \cdot 76 \\
11 \cdot 48 \\
16 \cdot 16 \\
10 \cdot 76\end{array}$ & $\begin{array}{l}0.95 \\
0.98 \\
0.99 \\
0.98\end{array}$ & E & $\overline{-}$ & $\overline{-}$ & $\begin{array}{l}-4 \cdot 23 \\
-4 \cdot 19 \\
-2 \cdot 30 \\
-2 \cdot 30\end{array}$ & $\begin{array}{l}2.91 \\
2.58 \\
2.71 \\
2.61\end{array}$ & $\begin{array}{l}-0.77 \\
-0.73 \\
-0.74 \\
-0.73\end{array}$ & $\begin{array}{l}- \\
-\end{array}$ & $\frac{-}{-}$ & $E$ \\
\hline
\end{tabular}

$b=$ regression coefficient $=\mu \mathrm{g} / \mathrm{DNA} / \mathrm{IO}^{8}$ cells; $r=$ correlation coefficient. 
dilution series within a strain. The addition of calf thymus DNA to each sample did not alter the final result except in the instances mentioned above.

These results are represented diagrammatically in Fig. I, where it can be seen that 2nL and its spore tetrads I and 8 are distinct from the diploid and haploid regression lines. The regression coefficients $\left(\mu \mathrm{g} \mathrm{DNA} / 10^{8}\right.$ cells) of the adenine-dependent strains are greater when extracts are measured from white, pigment-repressed cells than from red cells; this effect can be seen for the diploid 20/20, and $2 \mathrm{~nL}$ and its tetrads I and 8 (Fig. I). The regression line for white cells of the strain $20 / 20$ coincides with that for the other diploid strain 2nJ.

The slope of the regression lines, as indicated by the coefficient $b$ (Table I), is different for each strain and dependent upon the ploidy of that strain. DNA values for the same number of cells per strain have been noted in Fig. $\mathrm{I}$ : they approximate to a doubling series with ploidy.

The statistical significance of the differences in these regressions between strains can be demonstrated by covariance analysis. The results presented in Table 2 have been confined to the haploid and the two diploids for simplicity: the triploids and the tetraploid follow the same general pattern. First it is shown that the regressions of total DNA on yeast numbers for extracts from the haploids and the diploid, $2 \mathrm{~nJ}$, are significantly different; whereas extracts from white cells of $20 / 20$ are not significantly different from 2 nJ. The I \% level of significance was taken throughout. This reinforces the interpretations drawn from Fig. I that these regression lines are characteristic of the ploidy of a strain, as demonstrated by the juxtaposition of $2 \mathrm{~nJ}$ and $20 / 20$ white.

Table 2. Analysis of covariance between and within yeast strains and treatments

\begin{tabular}{|c|c|c|c|}
\hline $\begin{array}{l}\text { Subjects for } \\
\text { covariance analysis }\end{array}$ & $\begin{array}{l}\text { Variance } \\
\text { ratio } F^{*}\end{array}$ & $\begin{array}{l}\text { Degrees } \\
\text { of } \\
\text { freedom }\end{array}$ & Probability \\
\hline $\mathrm{n}$ and $2 \mathrm{~nJ}$ & $\frac{222 \cdot 69}{3 \cdot 95}=56 \cdot 36$ & $\mathrm{I}, \mathrm{I} 2$ & $\ll 0.01 \dagger$ \\
\hline $2 \mathrm{~nJ}$ and $20 / 20$ white & $\frac{23 \cdot 54}{3 \cdot 50}=6 \cdot 73$ & I, I 2 & $>0.01$ \\
\hline $\begin{array}{l}\mathrm{n} \text { dilutions of cells and } \mathrm{n} \\
\text { dilutions of extracts }\end{array}$ & $\frac{7 \cdot 76}{I \cdot 56}=4 \cdot 98$ & I, 12 & $>0.01$ \\
\hline $\begin{array}{l}\text { 2nJ dilutions of cells and } 2 \mathrm{~nJ} \\
\text { dilutions of extracts }\end{array}$ & $\frac{0.32}{2 \cdot 66}=0.12$ & I, 12 & $>0.01$ \\
\hline $\begin{array}{l}20 / 20 \text { dilutions of cells and } 20 / 20 \\
\text { dilutions of extracts }\end{array}$ & $\frac{5 \cdot 01}{\mathrm{I} \cdot \mathrm{I} 7}=4.29$ & I, I 2 & $>0.01$ \\
\hline $\begin{array}{l}\mathrm{n} \text { extracts alone and } \mathrm{n} \text { extracts }+ \\
\text { standard DNA }\end{array}$ & $\frac{0.07}{3.47}=0.02$ & I, 12 & $>0.01$ \\
\hline $\begin{array}{l}\text { 2nJ extracts alone and } 2 n J \\
\text { extracts + standard DNA }\end{array}$ & $\frac{4 \cdot 37}{3 \cdot 29}=I \cdot 33$ & I, I 2 & $>0.01$ \\
\hline $\begin{array}{l}\text { 20/20 (white) extracts alone and } \\
20 / 20 \text { (white) extracts + standard } \\
\text { DNA }\end{array}$ & $\frac{1 \cdot 07}{1 \cdot 95}=0.55$ & $\mathrm{I}, \mathrm{I} 2$ & $>0.01$ \\
\hline $20 / 20$ white and $20 / 20$ red & $\frac{7 \mathrm{I} \cdot 88}{\mathrm{I} \cdot 03}=69 \cdot 78$ & $\mathrm{I}, \mathrm{I} 2$ & $\ll 0.01 \dagger$ \\
\hline
\end{tabular}


It is also shown in Table 2 that in every instance there was no significant difference in the regression of total DNA on number of yeasts analysed as measured by a dilution series of extracts from that measured by a dilution series of cells, indicating that DNA was extracted with the same efficiency from small and large numbers of cells. In the Figures the regression lines are drawn from combined results of at least three experiments treated in both ways.

When DNA measurements were made on both yeast dilutions and extract dilutions from white cells of $2 \mathrm{~nJ}, 20 / 20$ and $n$ with equal amounts of calf thymus DNA added to each sample, there was no significant difference between these regression coefficients and those obtained in the absence of additional DNA for the same strain (Table 2). The results are therefore in agreement with the hypothesis that the two regression lines, as plotted in Fig. $2 a$, are parallel. These experiments were duplicated for the strain $20 / 20$ in its red and white forms. Extracts from white yeasts measured with and without additional DNA gave parallel regression lines in agreement with the above findings. However, when red yeasts were analysed in this way, the addition of calf thymus DNA to the sample extracts did not give results paralleling those from red yeasts measured alone, i.e. values slightly lower than those obtained for white cells of this strain. Instead, negative results were obtained, i.e. total DNA estimates were obtained that were less than the amount of added DNA, an apparent loss of DNA having occurred. The results were positive, or above the level of the additional DNA, only when small numbers of cells were analysed. With increasing numbers of cells per sample, or increasing sample concentration, there was a fall and tailing-off in DNA values (Fig. 2a). This is reflected in the negative regression coefficients $(b)$ for these samples in Table $\mathrm{I}$. Thus, the presence of the red pigment or some other accumulation product in extracts from adenine-dependent strains depressed the estimates of DNA content, and there was also a severe interaction between such extracts and calf thymus DNA.

Finally it is shown in Table 2 that the regressions of total DNA on yeast numbers for extracts from the red and white forms of $20 / 20$ are significantly different.

$2 \mathrm{~nL}$ and the members of its spore tetrads showed the same general response to these variations in procedure as did the members of the polyploid series. The differences in regression lines between and within strains have been analysed for their significance in Table 3. It is demonstrated that the regressions of total DNA on yeast numbers were significantly different from each other for extracts from white cells of $2 \mathrm{~nJ}, 2 \mathrm{~nL}$ and $\mathrm{n}$. (It has been shown in Table 2 that $20 / 20$ white is not significantly different from $2 \mathrm{~nJ}$.)

The regression lines obtained for the members of tetrad 8 from $2 \mathrm{~nL}$ are compared in Table 3 and show that with the exception of the regression of the cell dilution series of strain $8 \mathrm{~d}$, there is no significant difference between the estimation of DNA content among the haploid segregants from 2 nL. There was, however, a significant difference between 8 a, taken as a representative of the tetrad, and the haploid $n$ (Table 3).

The comparisons made in Table 3 are drawn from the data for adenine-repressed white cells of tetrad 8; measurements made on red cells show a further depression of the regression line away from the haploid level (Fig. I).

The estimates obtained after the addition of calf thymus DNA are included for comparison with the other estimates (Fig. $2 b$ ). They show the red-yeast effect, as described above.

Although the above statistical analyses strongly indicate a direct linear relationship between total DNA and number of yeast cells analysed over a wide range of cell concentrations, examination of the relationship between number of yeast cells analysed and DNA per cell showed that linearity did not hold when small numbers of yeasts were analysed. Curvilinear regression analyses of logarithmic transformations of DNA per $10^{8}$ yeasts on 


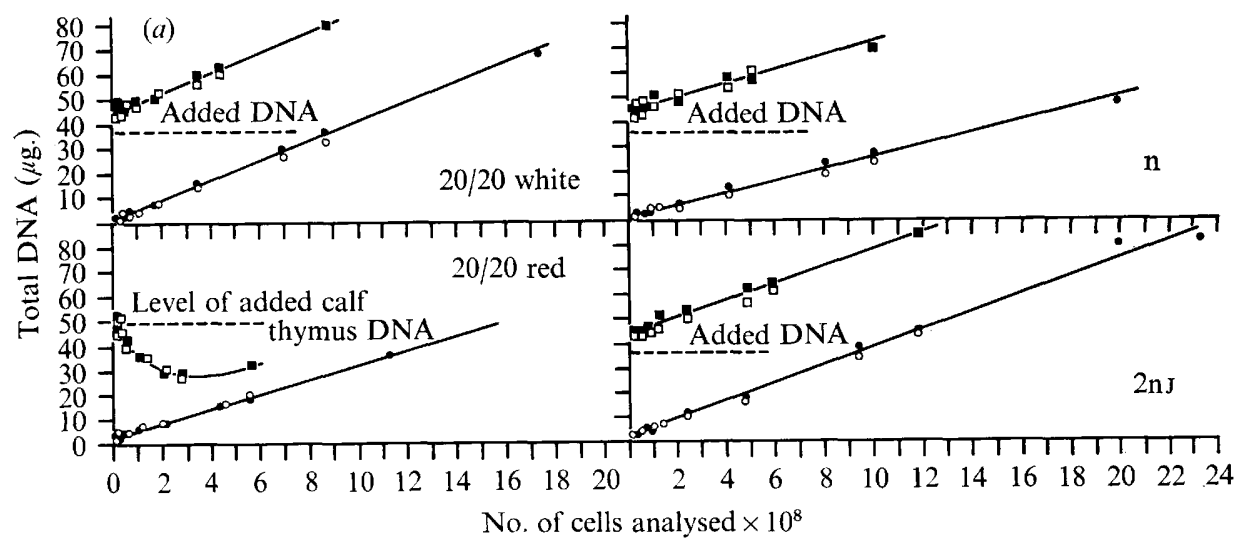

Fig. $2(a)$. Linear regressions of total DNA $(\mu \mathrm{g})$ on number of yeasts analysed for extracts from the haploid, $2 \mathrm{~nJ}$, and $20 / 20$ red and white yeasts measured alone or with the addition of calf thymus DNA. $\mathbf{n}$, Yeast extracts measured + calf thymus DNA; $\square$, dilutions of the most concentrated yeast extract measured + calf thymus DNA; $O$, yeast extracts measured alone; $O$, dilutions of the most concentrated yeast extract measured alone.

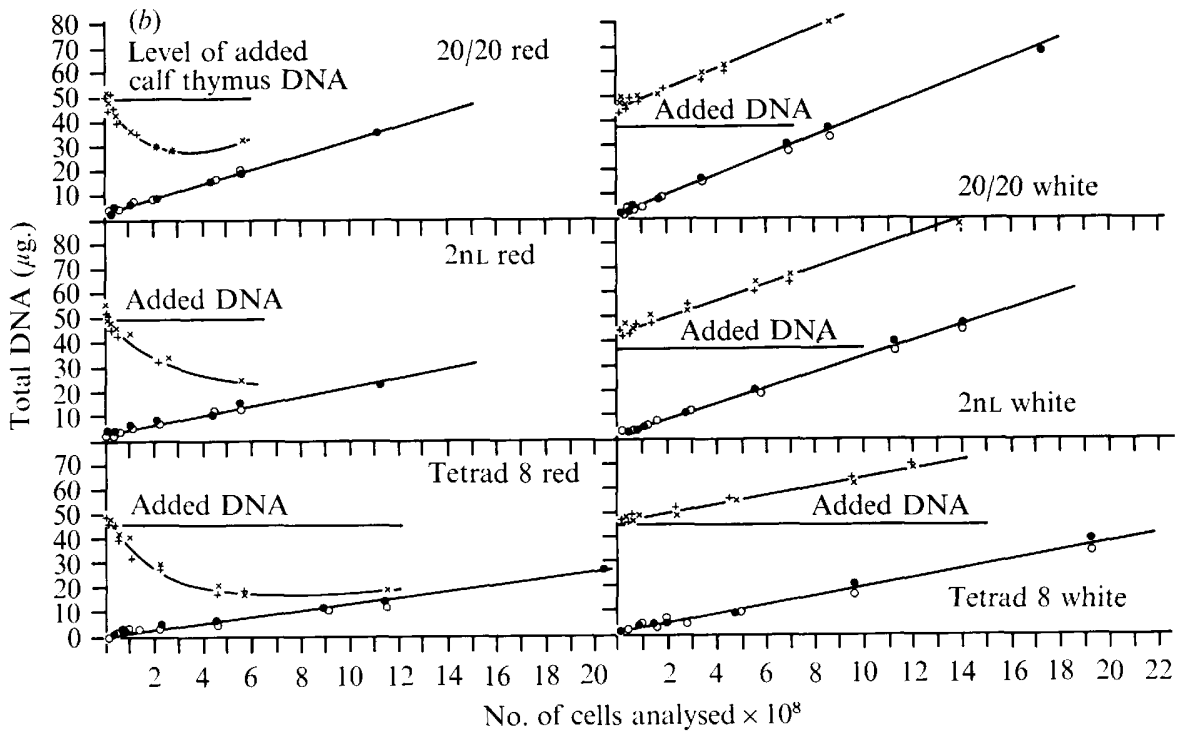

Fig. $2(b)$. Linear regressions of total DNA content on number of yeasts analysed for red compared with white cultures of the diploid $20 / 20,2 \mathrm{~nL}$ and the four members of tetrad 8 from $2 \mathrm{~nL}$, measured with and without the addition of calf thymus DNA. 0 , Yeast extracts measured alone; 0 , dilutions of the most concentrated yeast extract measured alone; $x$, yeast extracts measured +calf thymus DNA; + , dilutions of the most concentrated yeast extract measured + calf thymus DNA.

number of yeasts analysed was carried out as described under Methods. The results are summarized in Table 4 . The regression coefficients are all negative and the regressions are mainly significant at the I \% level, some only at the $5 \%$ level - and not as expected, i.e. zero or parallel to the abscissa. These results are shown diagrammatically in Fig. 3 and demonstrate the effect shown in Table 2 that the regression coefficients, or the slopes, are not greatly different from strain to strain, but they differ in elevation and are therefore 


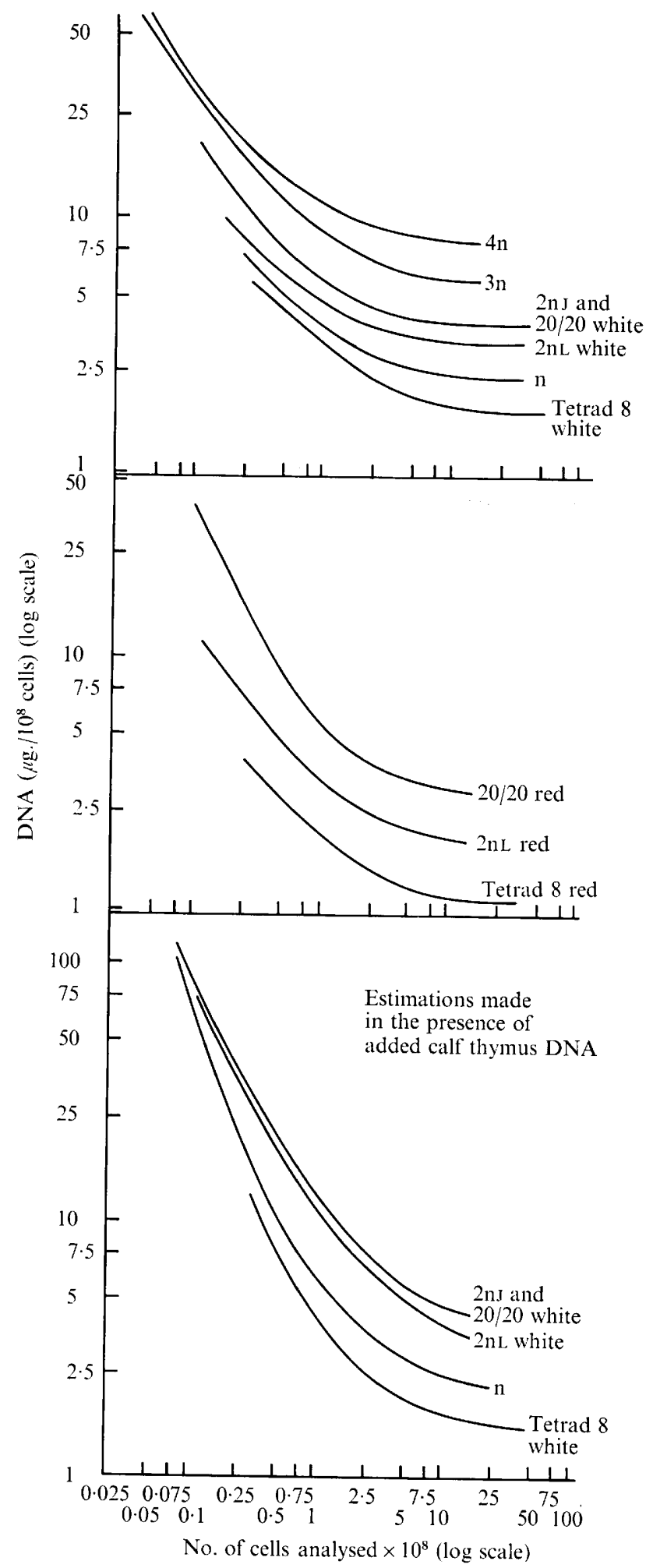

Fig. 3. For legend see opposite page. 
separate. It is also shown that the slope is influenced by the presence of the red pigment in strains $20 / 20,2 \mathrm{~nL}$ and its spore tetrads and by the addition of calf thymus DNA to all samples - both cause a steepening of the slopes. The regression lines were all steepest when small numbers of yeasts were analysed; there was a tailing-off effect when more than $3 \times 10^{8}$ yeasts were present in the sample and the lines became almost parallel to the $X$ axis. However, this cell number effect could not be attributed to the inefficient extraction of DNA from a large number of yeasts because of the agreement of results from the dilution series of extracts and cells.

These effects were specific for the diphenylamine reagent. Measurements of the absorbance of extracts at $260 \mathrm{~nm}$ provide constant estimates of DNA content over a wide range of cell concentrations (Fig. 4).

Table 3. Analysis of covariance between and within yeast strains and treatments

\begin{tabular}{|c|c|c|c|}
\hline $\begin{array}{c}\text { Subjects for } \\
\text { covariance analysis }\end{array}$ & $\begin{array}{l}\text { Variance } \\
\text { ratio } F^{*}\end{array}$ & $\begin{array}{l}\text { Degrees } \\
\text { of } \\
\text { freedom }\end{array}$ & Probability \\
\hline $2 \mathrm{~nL}$ white and $2 \mathrm{~nJ}$ & $\frac{68 \cdot 85}{5 \cdot 75}=\mathrm{II} \cdot 98$ & I, I 2 & $<0.0 I^{\dagger}$ \\
\hline $2 \mathrm{~nL}$ white and $\mathrm{n}$ & $\frac{72 \cdot 27}{4 \cdot 54}=15 \cdot 93$ & I, I 2 & $<0.0 \mathrm{I}^{\dagger}$ \\
\hline $2 \mathrm{~nL}$ red and $20 / 20 \mathrm{red}$ & $\frac{70 \cdot 83}{\mathrm{I} \cdot 02}=69 \cdot 72$ & I, I 2 & $\ll 0.01 \dagger$ \\
\hline $2 \mathrm{~nL}$ white and $2 \mathrm{~nL}$ red & $\frac{145 \cdot 26}{4.07}=35.69$ & $I, 12$ & $\ll 0.01 \dagger$ \\
\hline $\begin{array}{l}\text { 2nL dilutions of cells and } 2 \mathrm{~nL} \\
\text { dilutions of extracts }\end{array}$ & $\frac{0.33}{3 \cdot 18}=0.11$ & I, I 2 & $>0.01$ \\
\hline $\begin{array}{l}\text { 2nL extracts alone and } 2 \mathrm{~nL} \\
\text { extracts + standard DNA }\end{array}$ & $\frac{9 \cdot 90}{6 \cdot 29}=I \cdot 57$ & $I, \mathbf{I}$ & $>0.0 \mathrm{I}$ \\
\hline $8 a$ and $8 b$ & $\frac{7 \cdot 52}{6 \cdot 34}=I \cdot 19$ & I, 12 & $>0.01$ \\
\hline $8 a$ and $8 c$ & $\frac{8 \cdot 17}{2 \cdot 92}=2 \cdot 80$ & $\mathrm{I}, \mathrm{I} 2$ & $>0.01$ \\
\hline $8 \mathrm{a}$ and $8 \mathrm{~d}$ & $\frac{52 \cdot 15}{3 \cdot 38}=15 \cdot 43$ & I, I 2 & $<0.0{ }^{\dagger} \dagger$ \\
\hline $\begin{array}{l}\text { 8a dilutions of cells and } 8 \mathrm{a} \\
\text { dilutions of extracts }\end{array}$ & $\frac{8 \cdot 5 I}{I \cdot 30}=6 \cdot 56$ & I, I 2 & $>0.01$ \\
\hline $\begin{array}{l}8 \mathrm{~d} \text { dilutions of cells and } 8 \mathrm{~d} \\
\text { dilutions of extracts }\end{array}$ & $\frac{42 \cdot 93}{2 \cdot 89}=14 \cdot 86$ & I, I 2 & $<0.01 \dagger$ \\
\hline $8 \mathrm{a}$ and $8 \mathrm{~d}$ dilutions of extracts & $\frac{0.28}{I .69}=0.17$ & I, I 2 & $>0.0 \mathrm{I}$ \\
\hline+ Signific & $\begin{array}{l}\frac{7 \mathrm{I} \cdot 29}{2.53}=28.15 \\
\text { ater than tabula } \\
\text { ater } P=0.0\end{array}$ & $\begin{array}{l}\text { I, I } 2 \\
33 .\end{array}$ & $\ll 0.01 \dagger$ \\
\hline
\end{tabular}

Fig. 3. Curvilinear regressions of logarithmic transformations of DNA content $/ 10^{8}$ yeast cells on number of cells analysed for all strains red and white and in the presence of calf thymus DNA. The lines of regression are computer calculated lines of best fit from at least three independent experiments. 
Table 4. Summary of curvilinear regression analyses of DNA $(\mu g) / 10^{8}$ yeasts on number of cells analysed

\begin{tabular}{|c|c|c|c|c|c|c|c|c|c|c|c|c|}
\hline \multirow[b]{3}{*}{ Strain } & \multicolumn{6}{|c|}{ DNA measurements made upon the extracts alone } & \multicolumn{6}{|c|}{ DNA measurements made upon the extracts + standard DNA } \\
\hline & \multicolumn{3}{|c|}{ Cell dilutions } & \multicolumn{3}{|c|}{ Extract dilutions } & \multicolumn{3}{|c|}{ Cell dilutions } & \multicolumn{3}{|c|}{ Extract dilutions } \\
\hline & $b$ & $t^{*}$ & $r$ & $b$ & $t^{*}$ & $r$ & $b$ & $t^{*}$ & $r$ & $b$ & $t^{*}$ & $r$ \\
\hline $4 n$ & $\begin{array}{l}-0.23 \\
-0.28\end{array}$ & $\begin{array}{l}12 \cdot 20 \\
10 \cdot 48\end{array}$ & $\begin{array}{l}-0.98 \\
-0.98\end{array}$ & - & $=$ & $=$ & $=$ & $=$ & $=$ & - & - & $=$ \\
\hline $3 \mathrm{n}$ & -0.46 & $33 \cdot 28$ & -1.00 & - & - & - & - & - & - & - & - & - \\
\hline $2 \mathrm{~nJ}$ & $\begin{array}{l}-0.22 \\
-0.27 \\
-0.16 \\
-0.16 \\
-0.24\end{array}$ & $\begin{array}{l}4 \cdot 37 \\
2 \cdot 76 \\
2 \cdot 19 \\
5 \cdot 76 \\
3 \cdot 61\end{array}$ & $\begin{array}{l}-0.89 \\
-0.78 \\
-0.70 \\
-0.93 \\
-0.85\end{array}$ & $\begin{array}{c}\bar{Z} \\
-0.31 \\
-0.41\end{array}$ & $\begin{array}{c}\overline{-} \\
\overline{13 \cdot 64} \\
33 \cdot 87\end{array}$ & $\begin{array}{c}\bar{z} \\
- \\
-0.99 \\
-I \cdot 00\end{array}$ & $\begin{array}{l}-0.46 \\
-0.76 \\
-0.44 \\
-0.55 \\
-0.74\end{array}$ & $\begin{array}{r}4 \cdot 32 \\
39 \cdot 57 \\
4.55 \\
10 \cdot 99 \\
36 \cdot 16\end{array}$ & $\begin{array}{l}-0.89 \\
-1.00 \\
-0.90 \\
-0.98 \\
-1.00\end{array}$ & $\begin{array}{c}- \\
- \\
-0.27 \\
-0.64\end{array}$ & $\begin{array}{c}- \\
- \\
3.50 \\
16.82\end{array}$ & $\begin{array}{c}\overline{-} \\
-0.84 \\
-0.99\end{array}$ \\
\hline 20/20 white & -0.22 & $4 \cdot 18$ & -0.88 & -0.26 & $7 \cdot 42$ & -0.96 & -0.75 & $26 \cdot 80$ & $-1 \cdot 00$ & -0.73 & $2 \mathrm{I} \cdot 26$ & -0.99 \\
\hline $20 / 20 \mathrm{red}$ & $\begin{array}{l}-0.43 \\
-0.56\end{array}$ & $\begin{array}{r}4 \cdot 65 \\
26 \cdot 18\end{array}$ & $\begin{array}{l}-0.92 \\
-1.00\end{array}$ & $-\overline{0.56}$ & $\overline{20 \cdot 73}$ & $-\overline{0.99}$ & \} Negativ & sults & & & & \\
\hline 2nL white & $\begin{array}{l}-0.15 \\
-0.15\end{array}$ & $\begin{array}{r}2.03 \\
12.26\end{array}$ & $\begin{array}{l}-0.67 \\
-0.71\end{array}$ & $-\overline{0.43}$ & $\frac{-}{18.92}$ & $-\overline{0.99}$ & $\begin{array}{l}-0.61 \\
-0.88\end{array}$ & $\begin{array}{r}2 \cdot 24 \\
17 \cdot 01\end{array}$ & $\begin{array}{l}-0.70 \\
-0.99\end{array}$ & $-\overline{0.70}$ & $-\overline{21 \cdot 45}$ & $-\overline{0.99}$ \\
\hline $2 \mathrm{~nL}$ red & $\begin{array}{l}-0.34 \\
-0.33 \\
-0.48 \\
-0.40 \\
-0.62\end{array}$ & $\begin{array}{r}4.09 \\
6.10 \\
4.81 \\
13.82 \\
11.85\end{array}$ & $\begin{array}{l}-0.92 \\
-0.96 \\
-0.91 \\
-0.99 \\
-0.98\end{array}$ & $\begin{array}{l}\bar{Z} \\
\overline{-} \\
-0.44\end{array}$ & $\begin{array}{l}- \\
\overline{-} \\
6 \cdot 10\end{array}$ & $\begin{array}{c}\bar{z} \\
\overline{-} \\
-0.94\end{array}$ & Negative & & & & & \\
\hline $\mathbf{n}$ & $\begin{array}{l}-0.46 \\
-0.53 \\
-0.32 \\
-0.62 \\
-0.41\end{array}$ & $\begin{array}{l}6 \cdot 42 \\
5 \cdot 73 \\
8 \cdot 70 \\
7 \cdot 11 \\
3 \cdot 19\end{array}$ & $\begin{array}{l}-0.97 \\
-0.93 \\
-0.97 \\
-0.96 \\
-0.82\end{array}$ & $\begin{array}{c}E \\
\overline{-} \\
-0.44 \\
-0.52\end{array}$ & $\begin{array}{l}- \\
\overline{-} \\
15.09 \\
13.14\end{array}$ & $\begin{array}{c}\bar{Z} \\
-0.99 \\
-0.99\end{array}$ & $\begin{array}{l}- \\
-0.98 \\
-0.79 \\
-0.50 \\
-0.79\end{array}$ & $\begin{array}{r}- \\
36 \cdot 34 \\
13 \cdot 94 \\
7 \cdot 17 \\
20.51\end{array}$ & $\begin{array}{l}- \\
-\mathrm{I} \cdot 00 \\
-0.99 \\
-0.96 \\
-0.99\end{array}$ & $\begin{array}{l}\bar{z} \\
-0.23 \\
-0.77\end{array}$ & $\begin{array}{c}- \\
\overline{-} \\
2 \cdot 33 \\
11 \cdot 28\end{array}$ & $\begin{array}{c}= \\
\overline{-} \\
-0.72 \\
-0.98\end{array}$ \\
\hline $\begin{array}{r}\text { 2nL/8a white } \\
\text { 8b white } \\
\text { 8c white } \\
\text { 8d white }\end{array}$ & $\begin{array}{l}-0.40 \\
-0.24 \\
-0.41 \\
-0.27\end{array}$ & $\begin{array}{r}12 \cdot 17 \\
1.37 \\
3 \cdot 92 \\
1 \cdot 52\end{array}$ & $\begin{array}{l}-0.99 \\
-0.52 \\
-0.87 \\
-0.56\end{array}$ & $\begin{array}{l}-0.30 \\
-0.44 \\
-0.53 \\
-0.08\end{array}$ & $\begin{array}{l}7 \cdot 62 \\
2 \cdot 26 \\
9 \cdot 24 \\
0 \cdot 47\end{array}$ & $\begin{array}{l}-0.96 \\
-0.75 \\
-0.97 \\
-0.21\end{array}$ & $\begin{array}{l}-0.97 \\
-\mathrm{I} .04 \\
-0.62 \\
-0.94\end{array}$ & $\begin{array}{r}5.29 \\
2.94 \\
6.35 \\
10.20\end{array}$ & $\begin{array}{l}-0.62 \\
-0.83 \\
-0.94 \\
-0.98\end{array}$ & $\begin{array}{l}= \\
=\end{array}$ & $\begin{array}{l}\text { E } \\
\text { - }\end{array}$ & $\begin{array}{l}= \\
=\end{array}$ \\
\hline $\begin{array}{r}2 \mathrm{~nL} / 8 \mathrm{a} \text { red } \\
8 \mathrm{~b} \text { red } \\
8 \mathrm{c} \text { red } \\
8 \mathrm{~d} \text { red }\end{array}$ & $\begin{array}{l}-0.62 \\
-0.58 \\
-0.51 \\
-0.39\end{array}$ & $\begin{array}{r}9 \cdot 27 \\
22 \cdot 47 \\
0 \cdot 74 \\
1 \cdot 78\end{array}$ & $\begin{array}{l}-0.97 \\
-1.00 \\
-0.39 \\
-0.62\end{array}$ & $\begin{array}{l}-0.79 \\
-0.52 \\
-0.53 \\
-0.24\end{array}$ & $\begin{array}{l}9 \cdot 32 \\
3 \cdot 10 \\
3 \cdot 33 \\
2 \cdot 70\end{array}$ & $\begin{array}{l}-0.97 \\
-0.81 \\
-0.86 \\
-0.77\end{array}$ & Negative & & & & & \\
\hline $\begin{array}{r}\text { 2nL/Ia white } \\
\text { Ib white } \\
\text { Ic white } \\
\text { Id white }\end{array}$ & $\begin{array}{l}-0.02 \\
-0.05 \\
-0.28 \\
-0.33\end{array}$ & $\begin{array}{l}0 \cdot 32 \\
0.97 \\
1 \cdot 52 \\
6 \cdot 37\end{array}$ & $\begin{array}{l}-0.14 \\
-0.40 \\
-0.56 \\
-0.94\end{array}$ & $\begin{array}{l}- \\
= \\
=\end{array}$ & $\begin{array}{l}- \\
-- \\
-\end{array}$ & $\begin{array}{l}= \\
= \\
-\end{array}$ & $\begin{array}{l}-0.92 \\
-0.42 \\
-0.51 \\
-I \cdot 13\end{array}$ & $\begin{array}{l}5.02 \\
2.92 \\
5.04 \\
2 \cdot 14\end{array}$ & $\begin{array}{l}-0.91 \\
-0.79 \\
-0.39 \\
-0.73\end{array}$ & $\begin{array}{l}- \\
= \\
=\end{array}$ & $\begin{array}{l}\overline{-} \\
\bar{z}\end{array}$ & $\begin{array}{l}- \\
= \\
=\end{array}$ \\
\hline $\begin{array}{l}\text { 2nL/Ia red } \\
\text { Ib red } \\
\text { Ic red } \\
\text { Id red }\end{array}$ & $\begin{array}{l}-0.35 \\
-0.41 \\
-0.42 \\
-0.41 \\
-0.25\end{array}$ & $\begin{array}{l}3.92 \\
7.35 \\
2.80 \\
3.52\end{array}$ & $\begin{array}{l}-0.84 \\
-0.87 \\
-0.96 \\
-0.78 \\
-0.84\end{array}$ & $\begin{array}{l}= \\
=\end{array}$ & - & E & Negative & & & & & \\
\hline
\end{tabular}




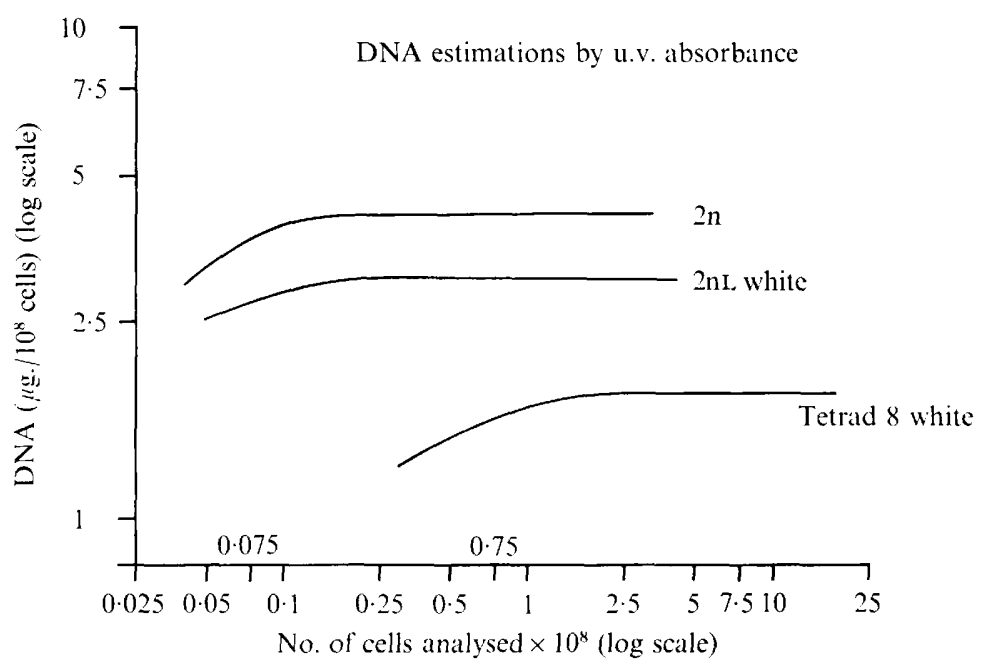

Fig. 4. Effect of sample size on DNA estimations by u.v. absorbance measurements at $260 \mathrm{~nm}$. Results for white cultures of a wild-type diploid, $2 \mathrm{~nL}$ and the four members of tetrad 8 from $2 \mathrm{~nL}$ are compared. They represent the combined results of two experiments each producing eight points.

The quantities of DNA for the same number of cells per strain are compared in Fig. I, and the mean regression values are summarized in Table 5. They indicate that $2 \mathrm{~nL}$ had approximately $18 \%$ less DNA than the two stock diploids, and its ascospore cultures had approximately $20 \%$ less DNA than the five stock haploids.

DNA was measured in some hybrid diploids (2nL spores $\times n$ ) and their tetrads. These analyses were not extensive, but are summarized in Table 6 . The hybrid diploids had normal diploid values for DNA content but there was great variation in DNA content between members of the tetrads derived from such hybrids. One ascospore culture, $4 \mathrm{~d}$, from the hybrid diploid $(2 \mathrm{~nL} / 8 \mathrm{a} \times \mathrm{n})$ had a diploid quantity of DNA and behaved as a normal diploid.

Growth studies. (I) Asynchronous. The rates of increase in yeast numbers when stationary phase cells of a diploid, a haploid and $2 \mathrm{~nL}$ were inoculated into fresh medium at a low cell concentration are shown in Fig. 5. They were similar to each other, but 2nL appeared to tail off more sharply once high yeast concentrations were reached than did either the diploid

Table 5. Summary of mean regressions ( $\mu \mathrm{g} D N A / 10^{8}$ cells)

\begin{tabular}{|c|c|c|c|c|}
\hline \multirow[b]{2}{*}{ Strain } & \multicolumn{2}{|c|}{ Without added DNA } & \multicolumn{2}{|c|}{ With added DNA } \\
\hline & $\begin{array}{c}\text { No. of } \\
\text { analyses }\end{array}$ & $\begin{array}{c}\text { Mean regression } \\
\left(\mu \mathrm{g} \text { DNA } / 10^{8}\right. \\
\text { cells })\end{array}$ & $\begin{array}{l}\text { No. of } \\
\text { analyses }\end{array}$ & $\begin{array}{c}\text { Mean regression } \\
\left(\mu \mathrm{g} \text { DNA } / 10^{8}\right. \\
\text { cells })\end{array}$ \\
\hline $4 n$ & 2 & $8 \cdot 42 \mathrm{I}$ & 一 & 一 \\
\hline $3 n$ & 2 & $6 \cdot 126$ & 一 & 一 \\
\hline $\begin{array}{l}2 \mathrm{~nJ} \\
20 / 20\end{array}$ & $\begin{array}{l}7 \\
4\end{array}$ & $\left.\begin{array}{l}3.732 \\
3.917\end{array}\right\} 3.825$ & $\begin{array}{l}7 \\
4\end{array}$ & $\left.\begin{array}{l}3.402 \\
3.470\end{array}\right\} 3.436$ \\
\hline 2nL & 3 & $3 \cdot 105$ & 3 & $2 \cdot 722$ \\
\hline $\mathrm{n}$ & 7 (5 strains) & $2 \cdot 435$ & 6 & 2.092 \\
\hline $2 \mathrm{~nL} / 8 \mathrm{a}-8 \mathrm{~d}$ & 2 & $I \cdot 843\}$ & $\mathbf{I}$ & $\mathrm{I} \cdot 60 \mathrm{I})$ \\
\hline $2 n L / I a-I d$ & I & $I \cdot 548\} I \cdot 696$ & I & $I \cdot 560\} I \cdot 5$ \\
\hline
\end{tabular}




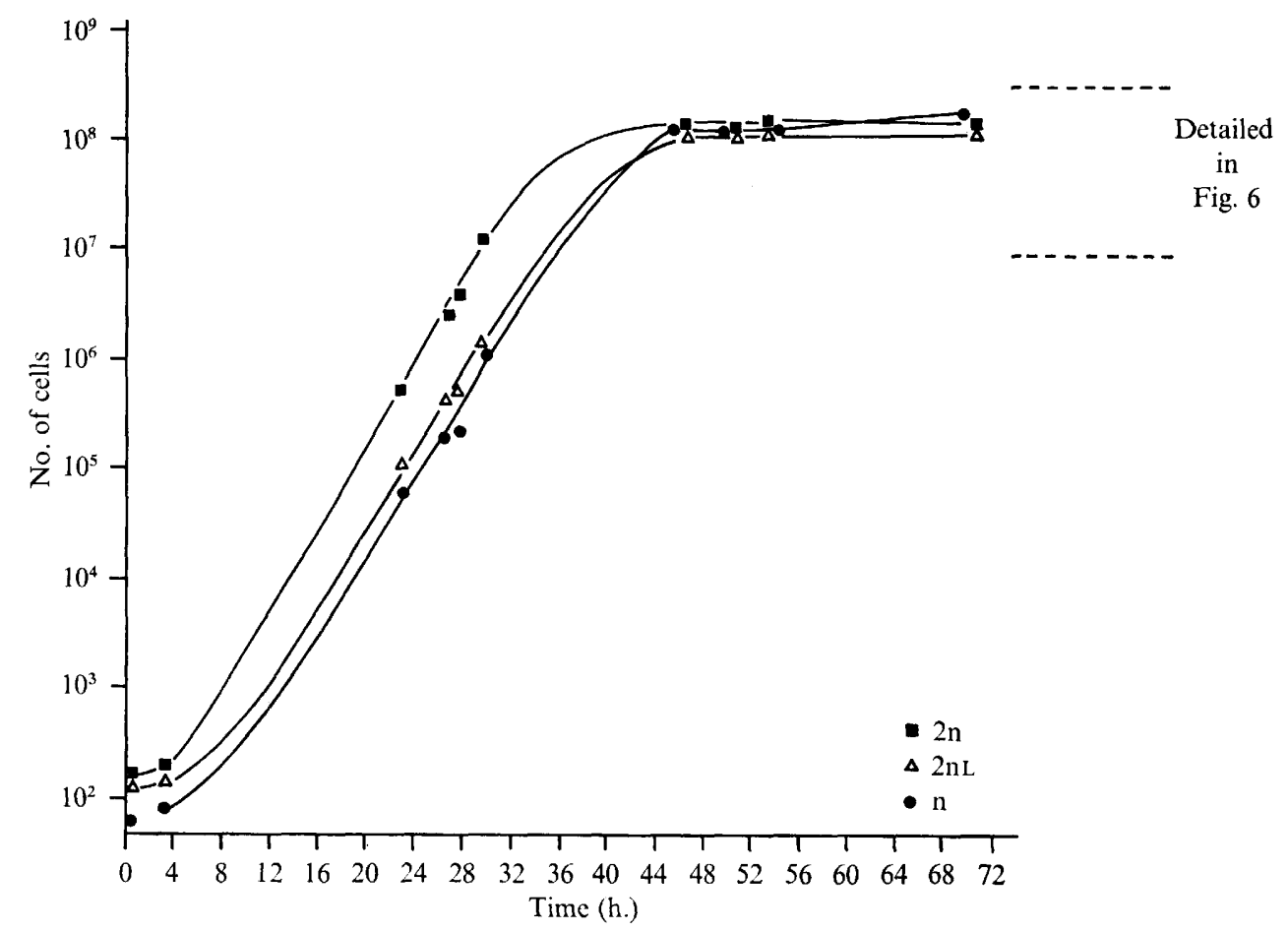

Fig. 5. Increase in yeast numbers from low yeast concentrations in cultures of $2 \mathrm{~nL}$ compared with a stock diploid and stock haploid cultures.

or haploid cultures. Since this may have been caused by an exhaustion of the growth medium, stationary phase cells of the same three strains were inoculated into fresh medium at high concentrations. The results are shown in Fig. 6. In a period of time when the stock diploid and haploid cultures increased their population size by a factor slightly greater than four,

Table 6. Summary of DNA contents of hybrid diploids (2nL spores $\times n$ ) and their segregants

\begin{tabular}{|c|c|c|c|c|c|}
\hline $\begin{array}{c}\text { Strain } \\
2 \mathrm{~nL} / 8 \mathrm{a} \times \mathrm{n}\end{array}$ & $\begin{array}{l}\text { DNA } \mu \mathrm{g} / 10^{8} \\
\text { cells } \pm \\
\text { standard error } \\
4.02 \pm 0.89\end{array}$ & $\begin{array}{c}\text { Strain } \\
2 \mathrm{~nL} / 8 \mathrm{c} \times \mathrm{n}\end{array}$ & $\begin{array}{c}\text { DNA } \mu \mathrm{g} / 10^{8} \\
\text { cells } \pm \\
\text { standard error } \\
4.06 \pm 0.6 \mathrm{I}\end{array}$ & $\begin{array}{c}\text { Strain } \\
2 \mathrm{~nL} / \mathrm{Ia} \times \mathrm{n}\end{array}$ & $\begin{array}{l}\text { DNA } \mu \mathrm{g} / \mathrm{IO}^{8} \\
\text { cells } \pm \\
\text { standard error }\end{array}$ \\
\hline $\begin{array}{l}4 a \\
4 b \\
4 c \\
4 d\end{array}$ & $\begin{array}{l}I \cdot 92 \pm 0.86 \\
I \cdot 62 \pm 0.36 \\
2 \cdot 84 \pm 0.20 \\
4 \cdot 32 \pm 0.45\end{array}$ & $\begin{array}{l}\text { II a } \\
\text { IIb } \\
\text { I Ic } \\
\text { IId }\end{array}$ & $\begin{array}{l}2.40 \pm 0.32 \\
I .42 \pm 0.4 I \\
2.94 \pm 0.46 \\
I .42 \pm 0.34\end{array}$ & $\begin{array}{l}\text { Ia } \\
\text { Ib } \\
\text { Ic } \\
\text { Id }\end{array}$ & $\begin{array}{l}3 \cdot 77 \\
4 \cdot 02 \\
1 \cdot 38 \\
3 \cdot 49\end{array}$ \\
\hline $\begin{array}{l}2 a \\
2 b \\
2 c \\
2 d\end{array}$ & $\begin{array}{l}2 \cdot 16 \\
2 \cdot 13 \\
1 \cdot 78 \\
2 \cdot 43\end{array}$ & $\begin{array}{l}2 \mathrm{a} \\
2 \mathrm{~b} \\
2 \mathrm{c} \\
2 \mathrm{~d}\end{array}$ & $\begin{array}{l}I \cdot 48 \\
2 \cdot 48 \\
2 \cdot 93 \\
4 \cdot 02\end{array}$ & $\begin{array}{l}2 \mathrm{a} \\
2 \mathrm{~b} \\
2 \mathrm{c} \\
2 \mathrm{~d}\end{array}$ & $\begin{array}{l}I \cdot 67 \\
3 \cdot 12 \\
3 \cdot 8 I \\
2 \cdot 14\end{array}$ \\
\hline $\begin{array}{l}5 \mathrm{a} \\
5 \mathrm{~b} \\
5 \mathrm{c} \\
5 \mathrm{~d}\end{array}$ & $\begin{array}{l}3 \cdot 07 \\
2 \cdot 18 \\
2 \cdot 03 \\
2 \cdot 48\end{array}$ & $\begin{array}{l}12 \mathrm{a} \\
12 \mathrm{~b} \\
12 \mathrm{c} \\
12 \mathrm{~d}\end{array}$ & $\begin{array}{l}4 \cdot 47 \\
2 \cdot 44 \\
I \cdot 96 \\
I \cdot 58\end{array}$ & & \\
\hline
\end{tabular}




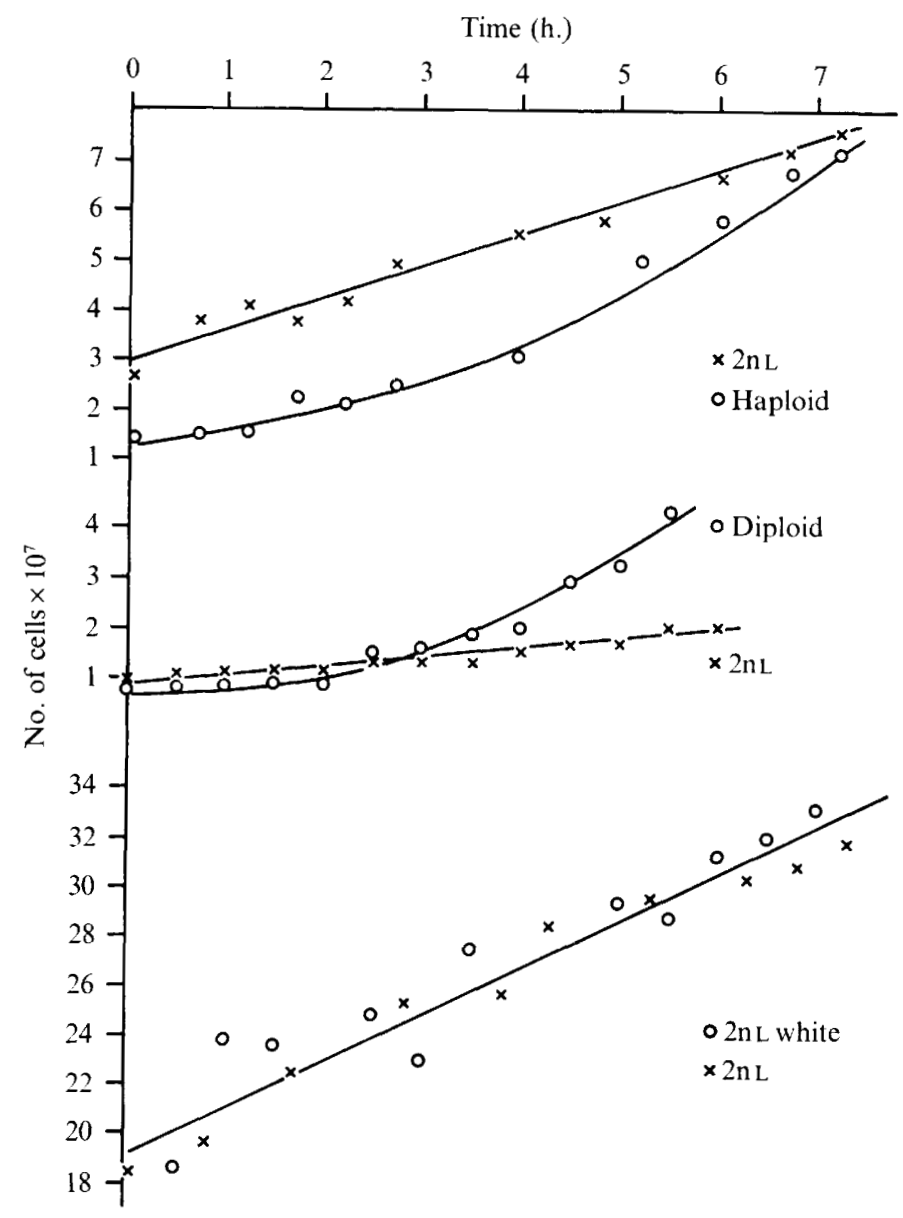

Fig. 6. Increase in yeast numbers in cultures of $2 \mathrm{~nL}$ inoculated into growth medium at a high concentration, compared with stock diploid and haploid cultures similarly treated.

$2 \mathrm{~nL}$ only doubled its population size. It was found that both $2 \mathrm{~nL}$ and the white form induced by the addition of an excess of adenine to the medium behaved in the same way.

When $2 n L$ was inoculated at high cell concentrations, its growth was linear, not exponential, i.e. in this culture the same number of cells divided in each cycle, not the same proportion as in exponential growth.

At the end of the growth period the percentage of cells, without visible buds, in the populations of $2 \mathrm{~nL}$ and $2 \mathrm{n}$ was $2 \cdot 4 \%$ for $2 \mathrm{n}$ and $20 \%$ for $2 \mathrm{~nL}$.

Besides counting, in a haemocytometer slide, the numbers of cells in cultures of strains $\mathrm{n}$, 2n and $2 \mathrm{~nL}$, samples were plated after appropriate dilution on to complete medium plates, and the number of viable colony-forming units was estimated. The results are compared in Table 7. There was agreement between the two methods for all three strains, and there was no obvious inviability in the strain $2 \mathrm{~nL}$.

(2) Synchronized growth. The results shown in Fig. 7 of the synchronized cell division of a population of yeasts of the strain $2 \mathrm{~nL}$, and the total DNA estimations on samples of these dividing yeasts, are based upon only one experiment. Nevertheless, they are included because of the demonstration that the order in which DNA doubling and cell doubling 


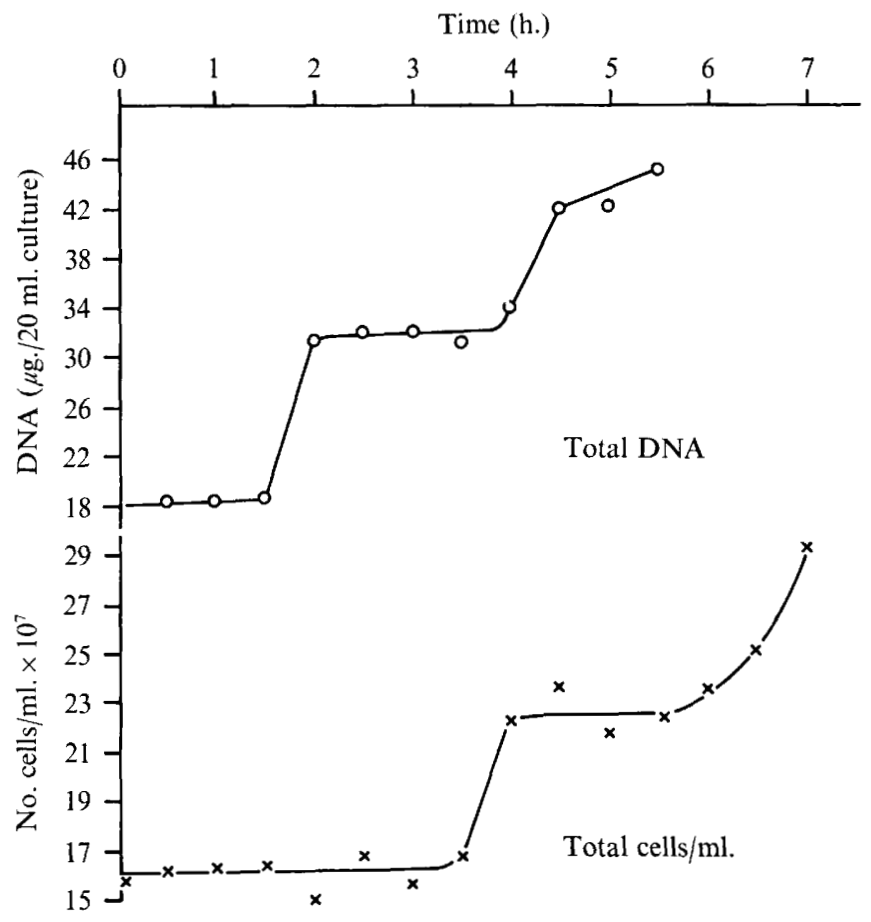

Fig. 7. Growth study of a synchronously dividing culture of $2 \mathrm{~nL}$ and DNA content $/ 20 \mathrm{ml}$ of culture. Samples taken initially and at $30 \mathrm{~min}$ intervals for yeast counting and DNA estimations.

occurred in this culture was normal (Williamson \& Scopes, I960). They also illuminate the result from the non-synchronized high yeast concentration growth studies, viz. that cell doubling was not complete. However, at such high yeast concentrations this was probably due to medium exhaustion.

The duration of the complete cell cycle was in good agreement with normal behaviour in yeast (Williamson \& Scopes, 1960).

Cellular inactivation by u.v. and $\gamma$-radiation treatments. The survival curve of each strain after treatment with u.v. and $\gamma$-radiations was determined by at least three replicate experiments and the averaged results for each point have been plotted. The survival curves for 2nL are compared with standard survival curves obtained for a series of haploid and diploid strains in Figs. 8 to Io. The survival curve for $2 \mathrm{~nL}$ after u.v. treatment is compared with the standard haploid survival curve in Fig. 8, and with the standard diploid survival curve in

Table 7. Comparison of plate counts of viable colonies with yeast counts

\begin{tabular}{ccc} 
Strain & \multicolumn{2}{c}{ Estimated titre of cells by } \\
\cline { 2 - 2 } ha & $\begin{array}{c}\text { Cell counts in a } \\
\text { haemocytometer slide }\end{array}$ & $\begin{array}{c}\text { Plate counts of } \\
\text { viable colonies }\end{array}$ \\
& $7.30 \times 10^{6}$ & $6.05 \times 10^{6}$ \\
$2 \mathrm{~nL}$ & $2.03 \times 10^{8}$ & $2.16 \times 10^{8}$ \\
& $4.15 \times 10^{6}$ & $5.48 \times 10^{8}$ \\
$\mathrm{n}$ & $1.68 \times 10^{8}$ & $1.44 \times 10^{8}$ \\
& $3.03 \times 10^{6}$ & $2.43 \times 10^{8}$ \\
& $1.70 \times 10^{8}$ & $1.49 \times 10^{8}$
\end{tabular}




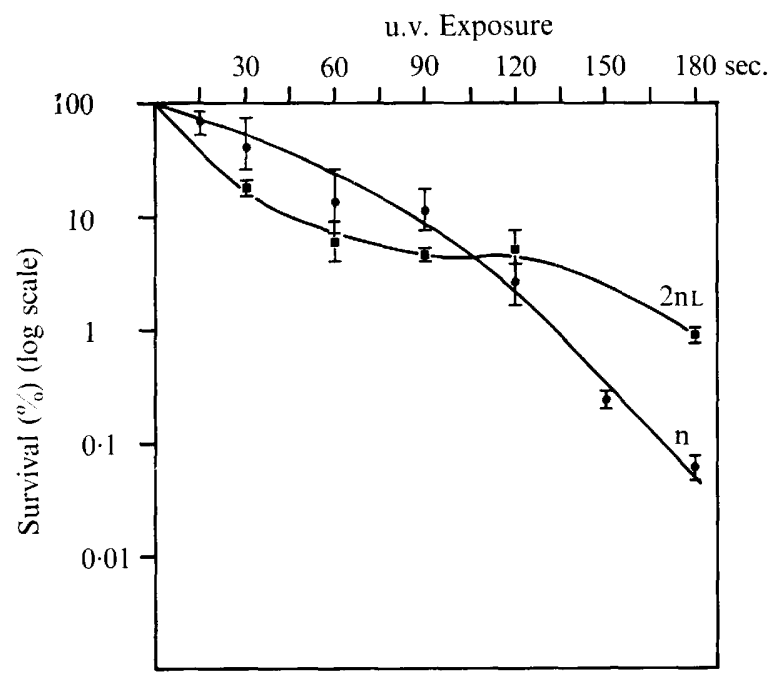

Fig. 8. The survival curve of $2 \mathrm{~nL}$ after u.v. irradiation compared with a standard haploid survival curve. The dose rate was $22 \mathrm{ergs} / \mathrm{sec} / \mathrm{mm}^{2}$ and the vertical bars represent $95 \%$ confidence limits.

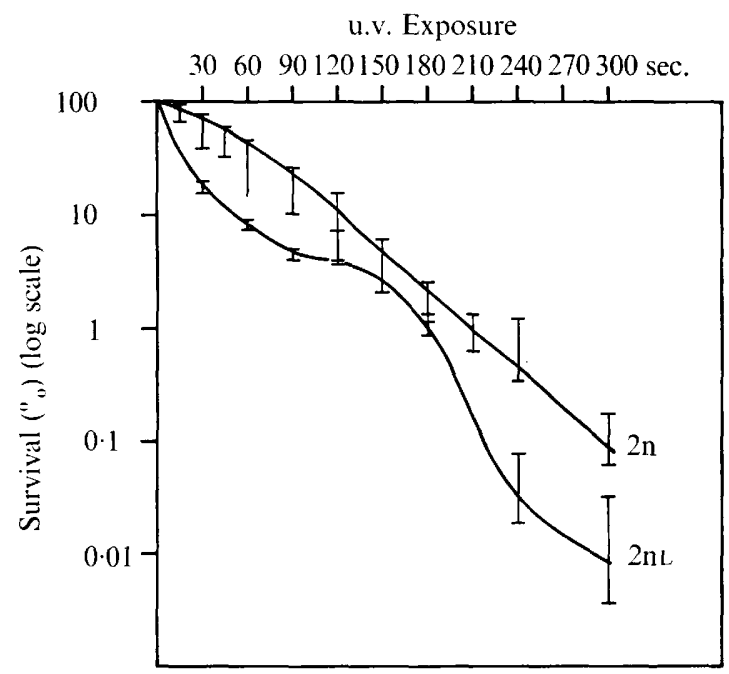

Fig. 9. The survival curve of $2 \mathrm{~nL}$ after u.v. irradiation compared with a standard diploid survival curve. The dose rate was $22 \mathrm{ergs} / \mathrm{sec} / \mathrm{mm}^{2}$ and the vertical bars represent $95 \%$ confidence limits.

Fig. 9. It has a complex shape, having lost the low-dose shoulder which is characteristic of u.v.-survival curves in many organisms treated under similar conditions, and it is therefore more sensitive to u.v. than a haploid at this low dose range. At approximately the $10 \%$ survival level there is a plateau in the survival curve of $2 \mathrm{~nL}$, where it is intersected by the haploid survival curve. With increasing dose survival decreases and it is intermediate between haploid and diploid in its sensitivity. It would appear that the characteristic shoulder region of a survival curve has shifted down the curve of $2 \mathrm{~nL}$ to a higher dose rate than usual.

In Fig. Io the survival response of $2 \mathrm{~nL}$ to $\gamma$-irradiation is compared with the stock haploid and diploid response. The haploid survival curve is a one-hit response, with a 'tailing-off' effect which is characteristic of haploid yeast (Beam, Mortimer, Wolfe \& Tobias, 1954). 


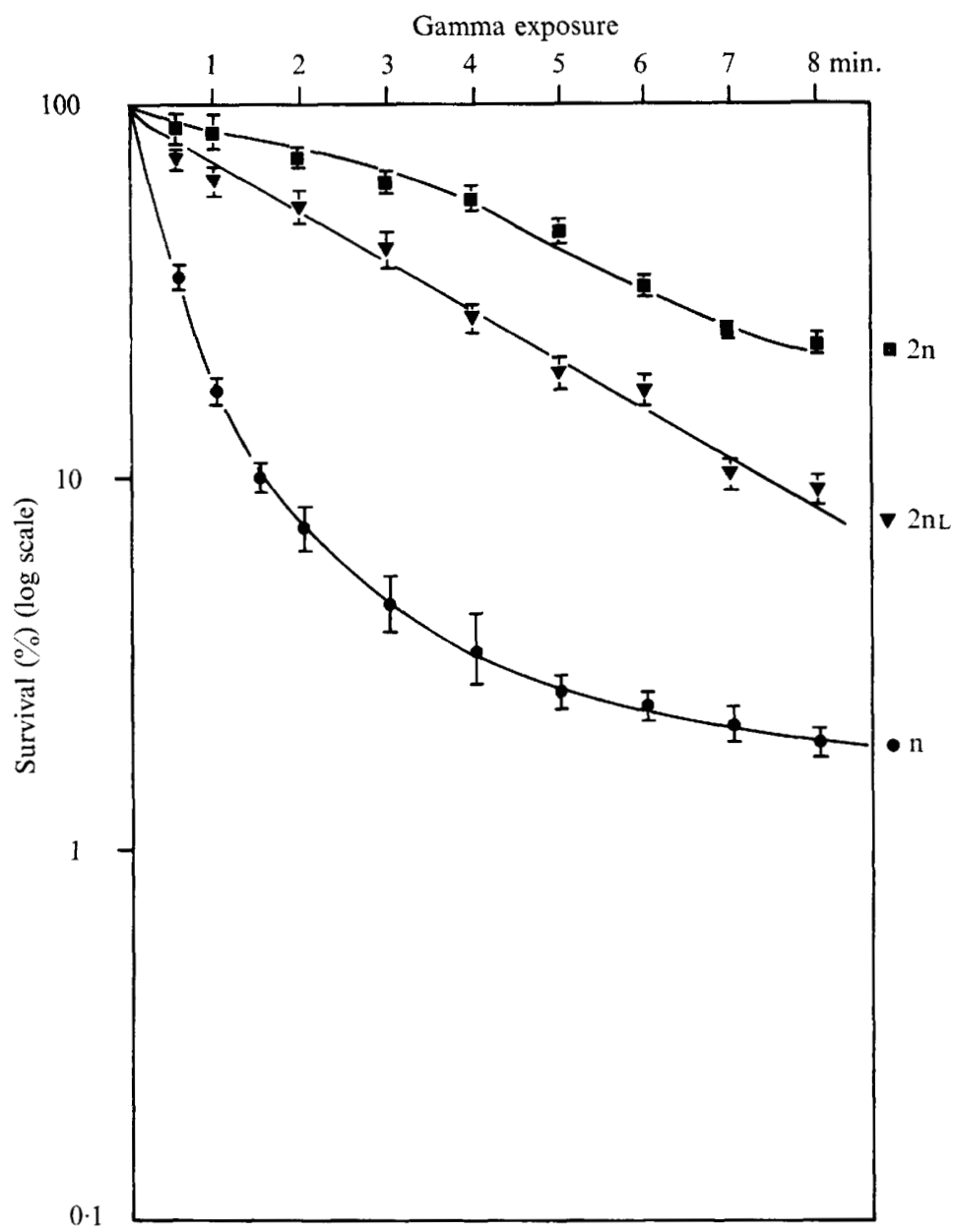

Fig. IO. The survival curve of 2 nL after gamma irradiation compared with standard haploid and diploid survival curves. The dose rate was $17 \mathrm{krad} / \mathrm{min}$ and the vertical bars represent $95 \%$ confidence limits.

The characteristic diploid yeast response to $\gamma$-irradiation is the sigmoid curve; $2 \mathrm{~nL}$ is more sensitive to $\gamma$-irradiation than a normal diploid and there is no shoulder in its survival curve.

\section{DISCUSSION}

The yeast culture $2 \mathrm{~nL}$ behaved as a normal diploid during genetic analysis but was distinguishable from other diploid strains on the basis of two separate criteria.

(I) It had $18 \%$ less DNA than had normal cells, and this low DNA value was independent of the method of DNA estimation, extraction techniques, or any of the parameters which may have influenced estimates of DNA content.

(2) The culture showed increased sensitivity to both u.v. and $\gamma$-irradiation.

Ogur et al. (1952) showed that DNA content varied during the budding cycle in yeast and demonstrated that DNA synthesis was completed before visible bud formation. Williamson (I965) also measured the timing of DNA synthesis in the cell cycle and showed that it was 
restricted to the first quarter, suggesting that stationary phase yeasts are in GI. It is possible that a postponement of DNA synthesis in a proportion of the cells of $2 \mathrm{~nL}$ could account for the low DNA values obtained, but such a misplacement of DNA synthesis at mitosis did not occur in the synchronous culture of this strain.

The growth studies did reveal a disturbed cell division at high cell concentrations although there was no loss of viability. This may have been connected with the low DNA values.

Since the observations of Mirsky \& Ris (I95I) concerning the wide range in DNA content of gametic nuclei of diploid chromosomal organisms, many other workers have confirmed and extended our knowledge of this variation. Variations in the quantity of DNA/nucleus have been demonstrated within all levels of classification down to the individual (Callan, I967; Jones \& Rees, 1968). Such variations have had various interpretations placed upon them by the different authors. Considering a change from a low to a high DNA content, there are two main hypothetical explanations: (i) that an increase in the number of lateral strands has occurred in the chromosomes; (ii) that extensive longitudinal repetition or accretion of genetic units has occurred.

Both imply that much of the DNA is either repetitive or redundant in the informational sense. Stebbins (1968) put forward a hypothesis associating the quantity of DNA with the genetic regulation of cellular metabolism by means of duplication of genetic information. He also points out that phylogenetic reduction in chromosome number is usually associated with the occurrence of unequal translocations between non-homologous chromosomes. Britten \& Kohne (1968) and Britten \& Davidson (1969) have discussed repetitive DNA and its possible role in the regulation of development. Walker (I97I) has discussed the possible structural importance of satellite DNA to the chromosomes and its possible role in controlling the process of homologous chromosome recognition at meiosis.

If repetitive DNA is at all common in yeast, it would seem likely that parts of it could be lost without lethal effect. Tetrad analysis of $2 \mathrm{~nL}$ showed that a translocation of met 2 to chromosome VII close to leuI and the centromere may have occurred. Such a translocation could have been accompanied by a loss of inessential DNA. The fact that meiosis was undisturbed in $2 \mathrm{~nL}$, but of reduced efficiency in the hybrid diploids derived from the crosses between $2 \mathrm{~nL}$ ascospore cultures and the stock cultures, may indicate a structural role for the missing DNA.

Moustacchi \& Williamson (1966) have reported the presence in yeast of satellite DNA bands of different buoyant density from the main nuclear DNA band. One satellite band is associated with the mitochondria, the other is of unknown location. $2 \mathrm{~nL}$ is not petite, but even in grande yeasts, the mitochondrial DNA fraction can vary considerably (Moustacchi \& Williamson, 1966). The amount of mDNA in normal yeasts is estimated to be in the region of $17 \%$ of the total DNA (D. H. Williamson, personal communication). It is certain that there are many copies of mDNA in normal cells. It is possible that 2 nL maintains only one or a few copies. This would account both for its grande phenotype and for its low DNA content. The other satellite fraction may also be involved in the loss.

The observation that $2 \mathrm{~nL}$ was intermediate between haploids and diploids in its sensitivity to u.v. and $\gamma$-radiations is in agreement with the hypothesis that it has a reduced target or chromosome volume. In classical target theory, lethality is regarded as the inevitable outcome of the accumulation of an appropriate number of physical 'hits' in the target volume (Lea, Haines \& Coulson, 1936). No allowance is made for the repair of induced damage. However, the shoulders on many survival curves are now attributed to the existence of repair processes which become saturated (Haynes, 1964, 1966). The absence of shoulders on these survival curves suggests that this strain's sensitivity could equally well be explained 
partly or totally by a defective repair system. Thus the lost DNA in this strain may have resulted in its increased sensitivity to radiations.

One of us (E. M. P.) is indebted to the Science Research Council which supported this work by a Research Studentship and post-doctoral Fellowship. The authors are grateful for the advice given and some determinations made by Dr D. H. Williamson. $\gamma$-Irradiation facilities were kindly provided by Professor D. R. Davies.

\section{REFERENCES}

BeAm, C. A., Mortimer, R. K., Wolfe, R. G. \& Tobias, C. A. (1954). The relation of radioresistance to budding in Saccharomyces cerevisiae. Archives of Biochemistry and Biophysics 49, IIO-122.

Bevan, E. A. \& Costello, W. P. (1964). The preparation and use of an enzyme which breaks open yeast asci. Microbial Genetics Bulletin 21, 5.

Boivin, A., Vendrely, R. \& Vendrely, C. (1948). L'acide désoxyribonucléique du noyau cellulaire, dépositaire des caractères héréditaires; arguments d'ordre analytique. Comptes rendus hebdomadaire des séances de l'Académie des sciences 226, 1061-1063.

Britten, R. J. \& Davidson, E. H. (1969). Gene regulation for higher cells: a theory. Science, New York I65, 349-357.

Britten, R. J. \& KohNe, D. E. (1968). Repeated sequences in DNA. Science, New York 16r, 529-533.

Burton, K. (1956). A study of the conditions and the mechanism of the diphenylamine reaction for the colorimetric estimation of DNA. Biochemical Journal 62, 315-323.

BURTON, K. (1968). Determination of DNA concentration with diphenylamine. In Methods in Enzymology, vol. XII, pp. I63-I 66. Edited by L. Grossman and K. Moldave. New York \& London: Academic Press.

Callan, H. G. (1967). The organization of genetic units in chromosomes. Journal of Cellular Science 2, I-7.

Cox, B. S. \& Bevan, E. A. (1962). Aneuploidy in yeast. New Phytologist 6r, 342-355.

HATChard, C. G. \& Parker, C. A. (1956). A new sensitive chemical actinometer. II. Potassium ferrioxalate as a standard chemical actinometer. Proceedings of the Royal Society A 235, 518-536.

HAYNES, R. H. (1964). Role of DNA repair mechanisms in microbial inactivation and recovery phenomena. Photochemistry and Photobiology 3, 429-450.

HAYNES, R. H. (I966). The interpretation of microbial inactivation and recovery phenomena. Radiation Research (Suppl.) 6, I-45.

Heagy, F. C. \& Roper, J. A. (I952). Deoxyribonucleic acid content of haploid and diploid Aspergillus conidia. Nature, London 170, 713-7I4.

Holliday, R. (196I). The genetics of Ustilago maydis. Genetical Research 2, 204-230.

HURST, D. D. \& FogEL, S. (1964). Mitotic recombination and heteroallelic repair in Saccharomyces cerevisiae. Genetics 5o, 435-458.

Jones, R. N. \& ReEs, H. (1968). Nuclear DNA variation in Allium. Heredity 23, 59I-605.

LEA, D. E., HAINes, R. B. \& Coulson, C. A. (1936). The mechanism of the bactericidal action of radioactive radiations. Proceedings of the Royal Society B 120, 47-66.

LeVINTHAL, N., Fogel, S. \& HURST, D. D. (I962). Genetic and biochemical analysis of purine biosynthetic pathway in Saccharomyces. Genetics 47 (abstr.), 967.

MIRSKY, A. E. \& Ris, H. (1949). Variable and constant components of chromosomes. Nature, London I63, 666-667.

MIRSKY, A. E. \& RIS, H. (195I). The DNA content of animal cells and its evolutionary significance. Journal of General Physiology 34, 45I-462.

MORTIMER, R. K. \& HAWTHORNE, D. C. (1966). Genetic mapping in Saccharomyces. Genetics 53, 165-173.

Moustacchi, E. \& Williamson, D. H. (I966). Physiological variations in satellite components of yeast DNA detected by density gradient centrifugation. Biochemical and Biophysical Research Communication 23, 56-6I.

Ogur, M., Minchler, S., Lindegren, G. \& Lindegren, C. C. (1952). The nucleic acids in a polyploid series of Saccharomyces. Archives of Biochemistry and Biophysics 40, 175-1 84 .

OGUR, M. \& Rosen, G. (I949). The nucleic acids of plant tissues. I. The extraction and estimation of deoxypentose nucleic acid and pentose nucleic acid. Archives of Biochemistry and Biophysics 25, 262-276. 
Pollister, A. W., SWIFT, H. \& Alfert, M. (195I). The desoxypentose nucleic acid content of animal nuclei. Experimental Cell Research (Suppl.) 2, 59-73.

StebBins, G. L. (1966). Chromosome variation and evolution. Science, New York 152, I463-I469.

WALKER, P. M. B. (1971). Origin of satellite DNA. Nature, London 229, 306-308.

Williamson, D. H. (I965). The timing of DNA synthesis in the cell cycle of Saccharomyces cerevisiae. Journal of Cell Biology 25, 517-528.

Williamson, D. H. \& SCOPES, A. W. (1960). The behaviour of nucleic acids in synchronously dividing cultures of Saccharomyces cerevisiae. Experimental Cell Research 20, 338-349.

Williamson, D. H. \& Scopes, A. W. (1962). A rapid method for synchronising division in Saccharomyces cerevisiae. Nature, London 193, 256-257. 